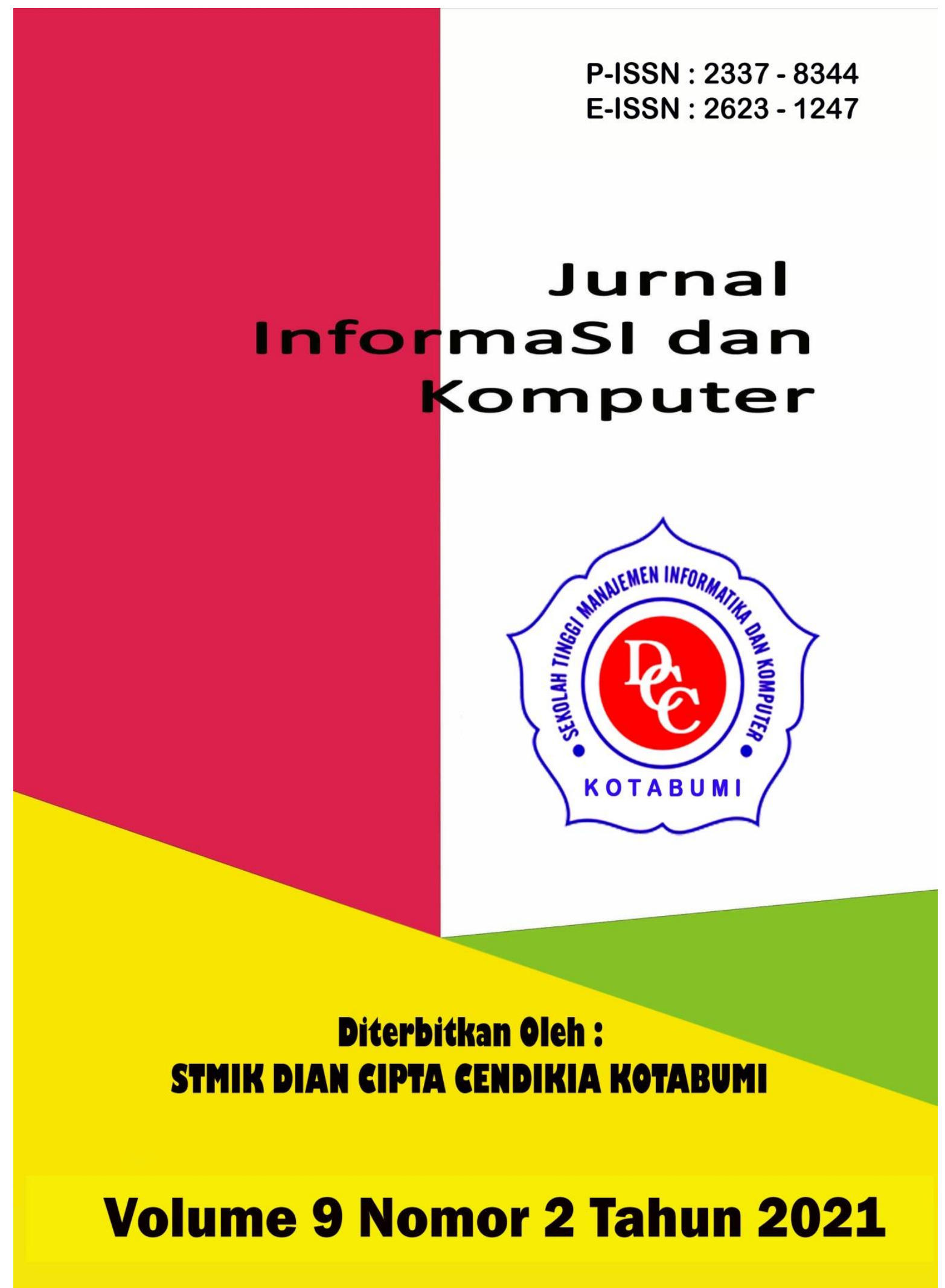




\section{Penerbit}

\section{Lembaga Penelitian STMIK Dian Cipta Cendikia Kotabumi}

Hak atas naskahh/tulisan tetap berada pada penulis, isi diluar tangung jawab penerbit dan Dewan Penyunting 


\section{PENGANTAR REDAKSI}

Puji syukur dipanjatkan kehadirat Tuhan Yang Maha Esa, atas karunia dan limpahan rahmatNYA jualah Jurnal Informasi dan komputer (JIK) STMIK Dian Cipta Cendikia Kotabumi ini dapat terwujud.Jurnal Informasi dan Komputer (JIK) yang terbit dua (2) kali dalam setahun ini merupakan suatu wadah untuk penyebar luasan hasil-hasil penelitian, studi pustaka, karya ilmiah yang berkaitan dengan Informasi dan Komputer khususnya bagi dosen-dosen STMIK Dian Cipta Cendikia Kotabumi serta umumnya para cendikiawan, praktisi, peneliti ilmu Informatika dan Komputer.

Harapan, dengan diterbitkannya Jurnal Informasi dan Komputer (JIK) ini sebagai salah satu bentuk sumbangan pemikiran dalam pengembangan ilmu informatika dan komputer yang berkaitan dengan kajian-kajian di bidang tekhnologi Informatik, Komunikasi Data dan Jaringan Komputer, perancangan dan Rekayasa Perangkat Lunak, serta ilmu-ilmu yang terkait dengan bidang Informasi dan Komputer lainnya.

Berkenaan dengan harapan tersebut, kepada para peneliti, dosen dan praktisi yang memiliki hasil-hasil penelitian, kajian pustaka, karya ilmiah dalam bidang tersebut diatas, dengan bangga redaksi Jurnal Informasi dan Komputer (JIK) menerima naskah ringkasan untuk dimuat pada jurnal Informasi dan Komputer (JIK) STMIK Dian Cipta Cendikia Kotabumi dengan berpedoman pada penulisan naskah jurnal sebagaimana dilampirkan pada halaman belakang (Bagian kulit dalam) buku jurnal ini.

Mutu dari suatu jurnal ilmiah tidak hanya ditentukan oleh para pengelolanya saja, tetapi para penulis dan pembaca jualah yang mempunyai peranan besar dalam meningkatkan mutu jurnal Informatika dan Komputer ini. Merujuk pada realita ini kamu sangat mengharapkan peran aktif dari peneliti untuk bersama-sama menjaga dan memelihara keberlangsungan dari jurnal Informasi dan Komputer STMIK Dian Cipta Cendikia Kotabumi ini. Yang juga tidak kalah pentingnya dari partisipasi tersebut diatas, adalah saran dan kritik yang membangun dari pembaca yang budiman agar kiranya dapat disampaikan langsung kepada redaksi JIK. Saran dan kritik yang membangun akan dijadikan masukan dan pertimbangan yang sangat berarti guna peningkatan mutu dan kualitas Jurnal Informasi dan Komputer STMIK Dian Cipta Cendikia Kotabumi.

Tak lupa diucapkan terima kasih yang tak terhingga atas perhatian dan kerjasama dari semua pihak yang tak dapat disebutkan satu persatu hingga dapat diterbitkan nya Jurnal Informasi dan Komputer (JIK) STMIK Dian Cipta Cendikia Kotabumi. Semoga apa yang telah diperbuat untuk kebaikan akan menjadi amal ibadah, amin.

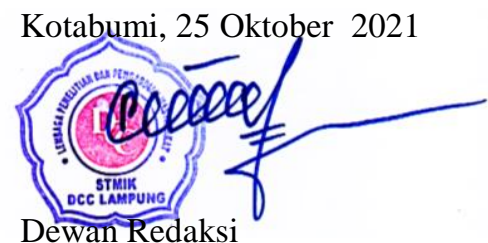




\section{JURNAL INFORMASI DAN KOMPUTER}

Volume 9 Nomor 2 Oktober 2021

Jurnal Informasi dan Komputer merupakan Sarana informasi ilmu pengetahuan, Tekhnologi dan Komunikasi yang berupa hasil penelitian, tulisan ilmiah, Ataupun studi pustaka. Jurnal ini terbit dua kali setahun pada bulan April dan Oktober. Berisi hasil penelitian ilmiah di bidang informatika yang bertujuan untuk menghubungkan adanya kesenjangan antar kemajuan teknologi dan hasil penelitian. Jurnal ini di terbitkan pertama kali pada tahun 2013.

Penanggung Jawab:

Ketua STMIK Dian Cipta Cendikia Kotabumi

\section{Pembina:}

Ketua STMIK Dian Cipta Cendikia Kotabumi Ketua Lembaga Penelitian STMIK Dian Cipta Cendikia Kotabumi

\section{Pimpinan Redaksi}

Dwi Marisa Efendi,.S.Kom.,M.Ti

\section{Redaksi pelaksana}

Rustam,.S.Kom,.M.Ti (STMIK Dian Cipta Cendikia Kotabumi)

Nurmayanti M.Kom (STMIK Dian Cipta Cendikia Kotabumi)

Sukatmi,.S.Kom., M.Kom (AMIK DCC Bandar Lampung)

Sampurna Dadi Riskiono,M.Kom (Universitas Teknokrat Indonesia)

Ifo Wahyu Pratama,S.Kom.,M.Ti(AMIK MASTER Lampung)

\section{Mitra Bestari}

Dr. RZ. ABDUL AZIZ, ST., MT (Institut Informatika dan Bisnis Darmajaya)

Dr. Dadang Sudrajat, S.Si, M.Kom (STMIK IKMI Cirebon)

Dr. Septafiansyah Dwi Putra, S.T., M.T (Politeknik Negeri Lampung)

Dr. Evi Grativiani, S.E., M.S.I (Universitas Sebelas Maret)

Rohmat Indra Borman ( Universitas Teknokrat Indonesia )

Ferry Wongso, S.KOm., M.Kom ( STMIK Darma Pala Riau)

Ferly Ardhy, S.Kom., M.Ti ( Universitas Aisyah Pringsewu )

Firmansyah, S.E., M.Si (STMIK Darma Pala Riau)
Amarudin (Universitas Teknokrat Indonesia)

Didi Susianto, S.T., M.Kom (AMIK Dian Cipta Cendika Bandar Lampung)

Alhibarsyah, St., M.Kom (STMIK Tunas

Bangsa Bandar Lampung)

Kemal Farouq Mauladi, S.Kom .M.Kom (Universitas Islam Lamongan)

Rima Mawarni, M.Kom ( STMIK Dian Cipta Cendikia Kotabumi)

Wira Jaya Hartono, S.Pd., M.Pd ( STMIK Darma Pala Riau)

Penerbit : STMIK Dian Cipta Cendikia Kotabumi Bekerja Sama Dengan LPPM STMIK Dian Cipta Cendikia Kotabumi.

\section{Alamat Redaksi/Penerbit:}

Jl. Negara No. 3 Candimas Kotabumi Lampung Utara

No Telpon/Fax 072423003

Email : 1ppm-stmik@dcc.ac.id 


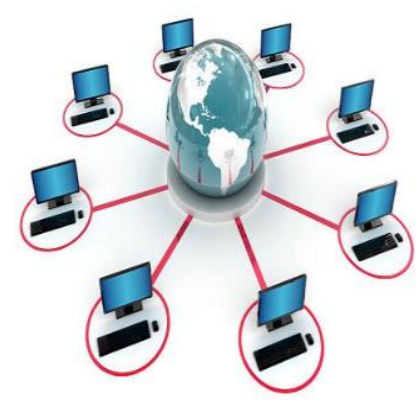

\section{JURNAL INFORMASI DAN KOMPUTER VOL. 9 NO. 2 THN. 2021}

\section{DAFTAR ISI}

Halaman

Sistem Informasi Akuntansi Persedian Barang Berbasis Web Pada Lembaga

Permasyarakatan Kelas II A Banceuy Bandung : "Kelompok Tani Desa Banjar Kertarahayu" Teuku Rian Hardiyansyah, Fatia Salsa Azzahra (Politeknik Piksi Ganesha Bandung ${ }^{1,2}$ )

Penerapan Finite State Automata Pada Vending Machine Penjual Obat Non Resep

Dokter Dan Keperluan Medis

Eko Supriyanto $^{1}$, Angga Ardiansyah ${ }^{2}$, Frieyadie $^{3}$, Sri Rahayu ${ }^{4}$, Windu Gata ${ }^{5}$

(Universitas Nusa Mandiri ${ }^{12}$ )

Sistem Pendukung Keputusan Untuk Menentukan Kelayakan Pengajuan Sertifikasi Guru Dengan Metode Simple Additive Weighting (Studi Kasus : Ma Al Muhajirin Janti Jogoroto Jombang)

Budiman, umam baharudin, winarti

(Universitas Darul 'Ulum Jombang)

Perancangan Infrastruktur Domain Name Server Lokal Menggunakan Ubuntu Server 16.04

Pada PT. Xyz

Zaenal Mutaqin Subekti, Hendra Setiawan, Satria, Widia Murni Wijaya,

Aliy Hafiz, Warsudi

(STMIK Bani Saleh, Universitas Negeri Yogyakarta, AMIK Dian Cipta Cendikia,

STMIK MIC CIkarang)

Perancangan Sistem Informasi Idea Proposal (Ip) Berbasis Web Pada Pt. Paxel Algorita Unggul

Julian Murhan Sahputra, Indah Purnamasari

(Universitas Nusa Mandiri ${ }^{12}$ )

Sistem Pendukung Keputusan Untuk Menentukan Ekstrakurikuler Atletik

Berdasarkan Bakat Siswa Menggunakan Metode Profile Matching

Agnes Basuki, Petrus Sokibi, Tiara Eka Putri

(Universitas Catur Insan Cendekia)

Penerapan Algoritma K-Means Untuk Pengelompokan Usia Calon Penerima Vaksin

Di Kab. Ngawi

Irna Yuniarfi, Saifulloh

(Universitas PGRI Madiun ${ }^{12}$ )

System Penilaian Seleksi Calon Karyawan Baru Menggunakan Metode Simple Additive Weighting (SAW) Di PT.TNA

Anik Sri Wahyuningsih, Yudhi Firmansyah

(Universitas Panca Sakti Bekasi ) 
Perancangan Sistem Informasi Pembayaran SPP Menggunakan Framework Laravel Ichwan Habib Moudi

(Universitas Panca Sakti Bekasi)

Implementasi Algoritma K-Means Dan Algoritma Apriori Optimasi Kinerja Ecu

(Study Kasus Mobil Avanza Dan Xenia)

Sigit Mintoro' Asep Afandi

(STMIK Dian Cipta Cendikia Kotabumi)

Sistem Pakar Penyakit Buah Kakao Untuk Peningkatan Hasil Panen Kakao Menggunakan

Metode Case Base Reasoning (CBR) Berbasis Web Mobile

Aliy hafiz, Verawati

(AMIK Dian Cipta Cendikia,Bandar Lampung)

Penerapan Metode Rapid Application Develomment (RAD) Dalam Pengembangan

Sistem Pemesanan Menu Berbasis Android

Aris Baihaqi, Tumini

(Fakultas Sains dan Teknologi ${ }^{1,2}$ )

Rancang Bangun Sistem Informasi Geografis Pariwisata Di Lampung Timur

Sukatmi, Rexa Alfa Rizi

(AMIK DCC Bandar Lampung ${ }^{12}$ )

Implementasi Psak No. 45 Pada Proses Penyusunan Laporan Keuangan Menggunakan

M.S. Excel Dan Aplikasi Accurate Accouting Pada STMIK Bani Saleh

Marhakim, Willy Adam

(STMIK Bani Saleh ${ }^{12}$ )

Sistem Prediksi Harga KOPI LAMBAR ( Lampung Barat) Dengan Metode

Backpropagation, dan Double Exponential ( Studi Kasus BUMDES )

Supriyanto, Dwi marisa Efendi,Rhomadhon

(STMIK Dian Cipta cendikia Kotabumi ${ }^{1-}$ )

Sistem Informasi Pemasaran Produk Umkm Berbasis Web Pada Kecamatan Bumi

Nabung Lampung Tengah

Yuli Syafitri, Agus Prasetyo, Reni Astika

(AMIK Dian Cipta Cendikia Bandar Lampung)

Rancang Bangun Aplikasi Pembelajaran Aksara Lampung Berbasis Android

Ferly Ardhy, Hendra Syahrobi

(Universitas Aisyah Pringewu ${ }^{1,}$ STMIK Dian Cipta Cendikia ${ }^{2}$ )

Sistem Pakar Diagnosa Penyakit Kulit Pada Balita Menggunakan Metode Naïve

Bayes Dan Forward Chaining Studi Kasus Puskesmas Cempaka Sungkai Selatan

Sidik Rahmatullah, Rima Mawarni

(STMIK Dian Cipta Cendikia Kotabumi ${ }^{12}$ )

Rekayasa Perangkat Lunak Perhitungan Harga Pokok Produksi Metode

Full Costing Pada Umkm Mitra Cake Di Bandar Lampung

Pitrawati, Arif Sanjaya

(AMIK Dian Cipta Cendikia, Bandar Lampung) 
Rancang Bangun Sistem Ujian Online Menggunakan Algoritma Cosine Similarity

Berbasis Web

Haryono, Zaenal Mutaqin Subekti, Widiyawati, Hidayatullah

(STMIK Bani Saleh ${ }^{1234}$ )

Model Aplikasi Helpdesk Ticketing System Berbasis Web Menggunakan Metode Rad

Indra Permana

Pattern Recognition Tulisan Tangan Huruf Hijaiyah Menggunakan Metode

Convolutional Neural Network (CNN)

Mufassiril Abror, Nopiyanto

(Universitas Panca Sakti Bekasi ${ }^{12}$ )

Aplikasi Sistem Informasi Keuangan Berbasis Android Di Perumahan Taman

Karang Bahagia

Melda Ayulestari

(Universitas Panca Sakti Bekasi)

Audit Pelayanan Sistem Rujukan Online Puskesmas Menggunakan Framework COBIT 5.0

Nurmayanti, Merri Parida, Ngajiyanto, Ina Anzalna

(STMIK Dian Cipta Cendikia Kotabumi ${ }^{1234}$ )

Perancangan Sistem Informasi Pengolahan Data Nilai Siswa Berbasis Web

Erin Ermawati, Anik Sri Wahyuningsih

(Fakultas Sain dan Teknologi, Universitas Panca Sakti Bekasi ${ }^{12}$ )

Pengembangan Sistem Pelaporan Data Hasil Inspeksi Barang Berbasis Web

Siska Putriani

(Universitas Pancasakti Bekasi)

Penerapan Extreme Programming Dalam Perancangan Aplikasi Web Food Market

Tumini, Hilman Septiana

(Fakultas Sains dan Teknologi Universitas Panca Sakti Bekasi ${ }^{1,2}$ )

Sistem Pencarian Barang Berbasis Website Menggunakan Php Dan Mysq1

Studi Kasus PT. Surya Technology Industri Sulaeman

(Universitas Panca Sakti Bekasi)

Implementasi Metode Prototype Pada Sistem Peminjaman Alat Kerja Berbasis Web

Di PT SK Metalindo

Ali Mulyanto, Arjun Gunawan

(Univeritas Panca Sakti Bekasi)

Aplikasi Tata Cara Wudhu Menggunakan Teknologi Augmented Reality

Sebagai Media Pembelajaran Di TK Al Fatih

Ahmad Yakub , Idarul Fadli

(Universitas Panca Sakti Bekasi ${ }^{12}$ )

Sistem Pakar Diagnosa Penyakit Ayam Petelur Menggunakan Metode Certainty Factor

Berbasis Web Mochammad

Taufiq Hidayat, Ali Mulyanto

(Universitas Panca Sakti Bekasi ${ }^{12}$ ) 
Penerapan Metode Prototyping Dalam Perhitungan Hasil Produksi Menggunakan

Arduino Uno R3 Dan Php Di PT. Indonesia Epson Industry

Amandha Aulia, Ajar Rohmanu

(Universitas Panca Sakti Bekasi ${ }^{12}$ )

System Pendukung Keputusan Penentuan Guru Teladan Dengan Metode Profile Matching

Hasbulloh, Agmawarnida

(Universitas Panca Sakti Bekasi ${ }^{1,2}$ )

Implementasi Waterfall Method Pada Aplikasi Buku Induk Siswa Berbasis Web

Idam Holid, Yogie Krisnayadi

(Universitas Panca Sakti ${ }^{12}$ )

Pengembangan Text To Speech Media Pembelajaran Untuk Pengenalan

Anggota Tubuh Manusia Kelas V Sekolah Dasar

Juwanda Saputra, Ali Mulianto

(Teknik Infomratika Fakulutas Sains dan Teknologi ${ }^{12}$ )

Perancangan Sistem Peminjaman Barang Berupa Aset Tetap Berbasis Web

Pada Lembaga Permasyarakatan Kelas II A Banceuy Bandung

Guntur Salasa Priambodo, Perwito, Candra Mecca Sufyana

(Politeknik Piksi Ganesha Bandung ${ }^{1,2,3}$ )

Metode Pemilihan Karyawan Terbaik Sebagai Penentu Goodwill Perguruan Tinggi

Dengan Menggunakan Metode Topsis (Studi Kasus Perguruan Tinggi Di Lampung Utara)

Dwi Sartika, Pakarti Riswanto

(STMIK Dian Cipta Cendikia Kotabumi)

Sistem Pendukung Keputusan Pemilihan Merek Smartphone Menggunakan

Metode Analytical Hierarchy Process (AHP)

Ade Kiki Fatmawati, Muhammad Sultan Raflie, Norma Yunita

(Universitas Nusa Mandiri ${ }^{123}$ )

Pattern Recognition Aksara Lampung Menggunakan Algoritma Neural Network

Metode Analytical Hierarchy Process (AHP)

Nopiyanto, Rahmadi

(Universitas Panca Sakti Bekasi) 


\title{
SISTEM PENDUKUNG KEPUTUSAN UNTUK MENENTUKAN EKSTRAKURIKULER ATLETIK BERDASARKAN BAKAT SISWA MENGGUNAKAN METODE PROFILE MATCHING
}

\author{
Agnes Basuki ${ }^{1}$, Petrus Sokibi ${ }^{2}$, Tiara Eka Putri ${ }^{3}$ \\ Universitas Catur Insan Cendekia \\ Jl. Kesambi No. 202 Kota Cirebon \\ agnes.basuki.5@gmail.com ${ }^{1}$, petrus.sokibi@cic.ac.id ${ }^{2}$, tiara.ekaputri@cic.ac.id ${ }^{3}$
}

\begin{abstract}
ABSTRAK
Prestasi atletik di SMP Negeri 17 Kota Cirebon harus dipertahankan dengan terus menggali dan mencari siswa yang memiliki potensi dan bakat di bidang atletik dari tahun ke tahun melalui kegiatan ekstrakurikuler. Namun terkait hal tersebut, tidak mudah bagi pihak sekolah untuk menentukan cabang olahraga mana yang sesuai dengan bakat siswa. Proses penentuan atletik siswa dilakukan melalui hasil tes masing-masing siswa. Hasil tes cenderung kurang objektif karena tidak ada faktor pendukung lainnya. Oleh karena itu, diperlukan suatu sistem yang dapat digunakan sebagai penelusuran dan penentuan bakat atletik siswa. Sistem Pendukung Keputusan dapat menjadi solusi untuk mempermudah dalam menentukan siswa atletik. Dengan adanya sistem ini diharapkan dapat memberikan informasi hasil penentuan kegiatan ekstrakurikuler atletik secara objektif. Penelitian ini menerapkan metode Profile Matching untuk menentukan ekstrakurikuler atletik siswa, dan sistem dibuat dalam bahasa pemrograman PHP dan SQL database menggunakan MySQL. Pada tahap perancangan sistem digambarkan menggunakan diagram UML. Hasil akhir dari penelitian ini diperoleh hasil penentuan cabang ekstrakurikuler atletik siswa dengan persentase keberhasilan perhitungan $100 \%$.
\end{abstract}

Kata kunci : Atletik, Bakat, Sistem Pendukung Keputusan, Profile Matching.

\begin{abstract}
S
Athletic achievements at SMP Negeri 17 Cirebon City must be maintained by continuing to explore and look for students who have potential and talent in athletic from year to year through extracurricular activities. However regarding this matter, it is not easy for the school to determine which athletic branch is in accordance with the talents of the students. The process of determining student athletic is carried out through the results of each student's test. The test results tend to be less objective because there are no other supporting factors. Therefore, a system is needed that can be used as a search and determination of student athletic talent. Decision Support Systems can be a solution to make it easier to determine student athletic. With this system, it is hoped that it can provide information on the results of determining athletic extracurricular activities objectively. This study applies the Profile Matching method to determine student athletic extracurriculars, and the system is made in the PHP programming language and SQL database using MySQL. At the system design stage, it is described using UML diagrams. The final result of this study obtained the results of determining the student's athletic extracurricular branch with a percentage of $100 \%$ calculation success.
\end{abstract}

Keywords: Athletic, Talent, Decision Support System, Profile Matching.

\section{PENDAhUluan}

Setiap sekolah memiliki berbagai macam ekstrakurikuler, salah satunya di SMP Negeri 17 Kota Cirebon terdapat beberapa ekstrakurikuler seperti atletik, voli, basket, futsal, dan lain-lain. Diantara ekstrakurikuler tersebut yang paling menonjol adalah atletik, karena sudah banyak prestasi yang dihasilkan oleh para siswa-siswi kepada pihak sekolah. 
Untuk mempertahankan prestasi tersebut pihak sekolah haruslah terus menggali dan mencari siswa-siswi yang memiliki potensi dan berbakat di bidang atletik dari tahun ke tahun. Namun mengenai hal tersebut tidaklah mudah bagi pihak sekolah dalam menentukan cabang atletik mana yang sesuai dengan bakat siswa. Proses penentuan cabang atletik siswa dilakukan melalui hasil tes uji masing-masing siswa. Contohnya siswa yang memiliki nilai yang bagus pada saat tes lari cepat akan diarahkan ke cabang atletik lari, siswa yang memiliki nilai yang bagus pada saat tes melempar akan diarahkan ke cabang atletik lempar, dan seterusnya.

Hasil tes tersebut cenderung kurang objektif karena tanpa adanya faktor pendukung lainnya seperti faktor kekuatan otot lengan dan otot tungkai serta faktor antropologi tubuh siswa. Selain itu, pihak sekolah juga kesulitan ketika mencari data-data siswa yang memiliki potensi di bidang atletik karena belum terkomputerisasi. Sistem Pendukung Keputusan (SPK) dapat menjadi solusi untuk dapat mempermudah dalam menentukan suatu pilihan. Salah satu metode yang dapat digunakan adalah metode Profile Matching.

Berdasarkan uraian permasalahan diatas, maka tujuan yang akan dilakukan pada penelitian ini adalah untuk membuat sistem berbasis web yang diharapkan dapat membantu dalam proses penentuan cabang atletik yang sesuai dengan bakat siswa dan penulis akan menerapkan metode profile matching untuk mendapatkan solusi pada penelitian ini ke dalam bentuk sistem pendukung keputusan dengan judul "Sistem Pendukung Keputusan Untuk Menentukan Ekstrakurikuler Atletik Berdasarkan Bakat Siswa Menggunakan Metode Profile Matching.

\section{TINJAUAN PUSTAKA}

\subsection{Sistem Pendukung Keputusan}

Sistem Pendukung Keputusan (SPK) atau Decision Support System (DSS), merupakan suatu sistem interaktif yang mendukung penentuan keputusan melalui alternatifalternatif yang diperoleh dari hasil pengolahan data, informasi dan perancangan model. SPK adalah sistem berbasis model yang terdiri dari prosedur-prosedur dalam pemrosesan data beserta pertimbangan-pertimbangannya, guna membantu manajer mengambil keputusan. Agar tujuannya tercapai, sistem harus dibuat sederhana, robust, mudah untuk dikontrol, mudah beradaptasi pada hal-hal penting, serta mudah dikomunikasikan [1].

\subsection{Bakat}

Bakat dapat diartikan sebagai sebuah kemampuan bawaan dari seseorang yang mana sebagai potensi yang masih perlu untuk dikembangkan lebih lanjut dan dilatih agar dapat mencapai impian yang ingin diwujudkan [2]. Bakat kemampuan dasar seseorang untuk belajar dalam tempo yang relatif pendek dibandingkan orang lain, namun hasilnya justru lebih baik. Bakat merupakan potensi yang dimiliki oleh seseorang sebagai bawaan sejak lahir.

\subsection{Atletik}

Atletik merupakan aktivitas jasmani atau latihan fisik, berisikan gerakan-gerakan alamiah dan wajar sesuai dengan apa yang dilaksanakan pada kehidupan kita sehari-hari seperti : jalan, lari, lempar, dan lompat. Atletik berasal dari bahasa Yunani yaitu "Athlon" yang berarti berlomba atau bertanding [3]. Istilah atletik yang digunakan di Indonesia mengacu pada bahasa Inggris yaitu "Athletic" yang berarti cabang olahraga yang meliputi jalan, lari, lempar, dan lompat [4].

\subsection{Profile Matching}

Metode profile matching memiliki tingkat obyektifitas yang lebih baik karena untuk mengukur nilai setiap indikator variabel penilaian diturunkan lagi dengan sub-indikator dan dibobotkan dengan menggunakan parameter penilaian serta dihitung dengan menggunakan mekanisme pengambilan keputusan dengan mengasumsikan bahwa terdapat tingkat variabel prediktor yang ideal yang harus dipenuhi oleh subyek [5]. Tahapan dalam metode profile matching sebagai berikut

\section{Menentukan Bobot Nilai Gap.}

Adapun dalam inputan dari proses pembobotan ini adalah selisih dari nilai anggota dan nilai target yang diinginkan. Pemetaan Gap, Gap yang dimaksud adalah perbedaan antara nilai target yang diinginkan dengan nilai anggota menggunakan persamaan 1 . 


\section{Gap =}

Nilai Anggota - Nilai Target

2. Perhitungan dan Pengelompokan Core Factor dan Secondary Factor.

Core Factor (Faktor Utama) merupakan aspek yang paling menonjol yang diperkirakan dapat menghasilkan kinerja optimal. Core factor dapat diperoleh dari hasil perhitungan menggunakan persamaan 2.

$$
N C F=\frac{\sum N C}{\sum I C}
$$

NCF adalah nilai rata-rata core factor, sedangkan $\Sigma \mathrm{NC}$ adalah jumlah total nilai core factor (aspek 1, aspek 2, aspek 3, dst.), dan $\Sigma$ IC adalah jumlah item core factor.

Secondary Factor merupakan item-item selain aspek yang ada pada Core Factor (Faktor Utama). Secondary factor dapat diperoleh dari hasil perhitungan menggunakan persamaan 3 .

$$
N S F=\frac{\sum N S}{\sum I S}
$$

NSF adalah nilai rata-rata secondary factor, sedangkan $\Sigma \mathrm{NS}$ adalah jumlah total nilai secondary factor (aspek 1, aspek 2, aspek 3, dst.), dan $\Sigma$ IS adalah jumlah item secondary factor.

\section{Perhitungan Nilai Total Aspek.}

Nilai total aspek pada penelitian ini dapat diperoleh dari hasil perhitungan menggunakan persamaan 4 .

$$
\text { nilai total }=(x) \% N C F+(x) \% N S F
$$

NCF adalah nilai rata-rata core factor, sedangkan NSF adalah nilai rata-rata secondary factor, dan (x)\% adalah nilai persen yang diinputkan.

\section{Perangkingan}

Perangkingan dilakukan berdasarkan hasil akhir yang diperoleh menggunakan persamaan 5 .

$$
\text { Hasil Akhir }=(x) \% N 1+
$$

$$
(x) \% N 2+(x) \% N 3+\cdots
$$

$\mathrm{N} 1$ adalah nilai total aspek 1, N2 adalah nilai total aspek 2, N3 adalah nilai total aspek 3 dan (x)\% adalah nilai persen rumus hasil akhir (total 100\%).

\section{METODE PENELITIAN}

\subsection{Metode Pengembangan Sistem}

Metode pengembangan perangkat lunak yang digunakan pada penelitian ini menggunakan metode Waterfall. Pada metode ini memiliki 5 (lima) tahap yang saling berkaitan seperti berikut :

\section{Requirement (Analisa Kebutuhan Sistem)}

Tahap ini meliputi identifikasi masalah yang ada, mendefinisikan masalah menjadi kebutuhan sistem serta melakukan pemahaman teori profile matching untuk melakukan evaluasi potensi atletik siswa.

2. Design (Desain)

Tahap perancangan sistem akan menerjemahkan syarat kebutuhan dalam sebuah perancangan perangkat lunak sebelum tahap pengkodean.

3. Implementation (Implementasi)

Tahap ini merupakan proses untuk menerjemahkan keseluruhan desain sistem yang telah dirancangan menjadi kode-kode program sehingga menghasilkan suatu sistem secara keseluruhan. Bahasa pemrograman yang digunakan dalam sistem ini adalah PHP, dan SQL database yang digunakan adalah MySQL.

4. Verification (Verifikasi)

Tahapan ini merupakan pengujian terhadap sistem yang telah dibuat untuk memastikan kesesuaian dengan tahap analisis dan desain yang telah dilakukan. Pengujian sistem dilakukan dengan Black Box.

5. Maintenance (Perawatan)

Tahap terakhir adalah tahapan perawatan atau pemeliharaan sistem, yang didalamnya ada proses instalasi dan proses perbaikan sistem apabila ditemukan kesalahan yang tidak terdeteksi pada tahap verifikasi.

\subsection{Analisis Sistem Yang Sedang Berjalan}

Pembina ekstrakurikuler atletik yaitu guru olahraga SMP Negeri 17 Cirebon melakukan 
penilaian tes atletik siswa. Dari penilaian tes atletik siswa tersebut didapat data nilai tes atletik siswa. Lalu, Pembina ekstrakurikuler atletik menentukan cabang ekstrakurikuler atletik siswa berdasarkan hasil nilai tes atletik. Dari penentuan cabang ekstrakurikuler atletik siswa didapat data hasil penentuan ekstrakurikuler atletik siswa. Pembina ekstrakurikuler atletik memberikan data hasil penentuan ekstrakurikuler atletik siswa kepada kepala sekolah agar kepala sekolah dapat melihat data hasil penentuan ekstrakurikuler atletik siswa SMP Negeri 17 Kota Cirebon.

\subsection{Analisis Kebutuhan Sistem Usulan}

Pada bagian analisis kebutuhan sistem usulan ini akan dijelaskan 2 bagian yaitu kebutuhan fungsional, dan kebutuhan non-fungsional.

\section{a. Kebutuhan Fungsional}

Kebutuhan fungsional berisi proses-proses apa saja yang dapat dilakukan oleh sistem, serta informasi apa saja yang harus ada dan dihasilkan. Berikut proses-proses yang ada pada Sistem pendukung keputusan untuk menentukan ekstrakurikuler atletik berdasarkan bakat siswa :

1. Sistem dapat menampilkan menu pilihan pada setiap masing-masing level user.

2. Sistem dapat menampilkan serta melakukan proses pengelolaan data alternatif anggota seperti menambahkan, mengedit, dan menghapus data alternatif anggota.

3. Sistem dapat menampilkan serta melakukan proses pengelolaan data kriteria (aspek) seperti menambahkan, mengedit, dan menghapus data kriteria (aspek).

4. Sistem dapat menampilkan serta melakukan proses pengelolaan data sub kriteria seperti menambahkan, mengedit, dan menghapus data sub kriteria.

5. Sistem dapat menampilkan data bobot Gap.

6. Sistem dapat menampilkan data penilaian serta melakukan proses pengelolaan data penilaian seperti menambahkan, dan mengedit data penilaian.

7. Sistem dapat menampilkan data hasil perhitungan menggunakan metode profile matching, mencetak hasil perangkingan dan penentuan ekstrakurikuler atletik siswa berdasarkan hasil perhitungan metode profile matching.

8. Sistem dapat menampilkan dan mengelola data user seperti menambahkan, mengedit, dan menghapus data user.

b. Berikut kebutuhan non-fungsional yang dibutuhkan dalam perancangan dan pembuatan Sistem pendukung keputusan untuk menentukan ekstrakurikuler atletik berdasarkan bakat siswa :

1. Seperangkat PC menggunakan SO Windows.

2. Website yang dibuat menggunakan framework CodeIgniter.

3. Sistem ini dapat digunakan oleh 2 user yakni admin, dan kepala sekolah SMP Negeri 17 Cirebon.

4. XАMPP server.

5. Mozilla Firefox, Google Chrome, dan Internet Explorer sebagai browser.

\subsection{Perhitungan Manual Metode Profile Matching}

Pada penelitian ini metode Profile Matching digunakan untuk memecahkan permasalahan untuk menentukan ekstrakurikuler atletik siswa. Perhitungan manual ini dibuat menggunakan Microsoft Excel. Berikut tahapan metode profile matching untuk proses perhitungan untuk ekstrakurikuler atletik siswa :

\section{Penentuan Range Nilai}

Range nilai yang akan digunakan dalam proses penentuan nilai target dan proses konversi nilai awal seperti berikut :

Tabel 1. Range Nilai Lari $30 \mathrm{M}$

\begin{tabular}{|c|c|}
\hline \multicolumn{2}{|c|}{ Data Range Nilai } \\
\hline 1 & $>=5,89$ detik \\
\hline 2 & $5,43-5,88$ detik \\
\hline 3 & $4,97-5,42$ detik \\
\hline 4 & $4,51-4,96$ detik \\
\hline 5 & $<=4,50$ detik \\
\hline
\end{tabular}


Tabel 2. Range Nilai Indeks Massa Tubuh

\begin{tabular}{|c|c|}
\hline \multicolumn{2}{|c|}{ Data Range Nilai } \\
\hline 1 & $<=18,5 \mathrm{~kg} / \mathrm{m}^{3}$ \\
\hline 2 & $18,6-20,1 \mathrm{~kg} / \mathrm{m}^{3}$ \\
\hline 3 & $20,2-21,7 \mathrm{~kg} / \mathrm{m}^{3}$ \\
\hline 4 & $21,8-23,3 \mathrm{~kg} / \mathrm{m}^{3}$ \\
\hline 5 & $23,4-24,9 \mathrm{~kg} / \mathrm{m}^{3}$ \\
\hline
\end{tabular}

Tabel 3. Range Nilai Vertical Jump

\begin{tabular}{|c|c|}
\hline \multicolumn{2}{|c|}{ Data Range Nilai } \\
\hline 1 & $<=20 \mathrm{~cm}$ \\
\hline 2 & $21-30 \mathrm{~cm}$ \\
\hline 3 & $31-40 \mathrm{~cm}$ \\
\hline 4 & $41-50 \mathrm{~cm}$ \\
\hline 5 & $>=51 \mathrm{~cm}$ \\
\hline
\end{tabular}

Tabel 4. Range Nilai Lempar Ban

\begin{tabular}{|c|c|}
\hline \multicolumn{2}{|c|}{ Data Range Nilai } \\
\hline 1 & $<=1,50 \mathrm{~m}$ \\
\hline 2 & $1,51-1,99 \mathrm{~m}$ \\
\hline 3 & $2,00-2,48 \mathrm{~m}$ \\
\hline 4 & $2,49-2,97 \mathrm{~m}$ \\
\hline 5 & $>=2,98 \mathrm{~m}$ \\
\hline
\end{tabular}

Tabel 5. Range Nilai Tinggi Badan

\begin{tabular}{|c|c|}
\hline \multicolumn{2}{|c|}{ Data Range Nilai } \\
\hline 1 & $<=145 \mathrm{~cm}$ \\
\hline 2 & $146-151 \mathrm{~cm}$ \\
\hline 3 & $152-157 \mathrm{~cm}$ \\
\hline 4 & $158-163 \mathrm{~cm}$ \\
\hline 5 & $>=164 \mathrm{~cm}$ \\
\hline
\end{tabular}

Tabel 6. Range Nilai Berat Badan

\begin{tabular}{|c|c|}
\hline \multicolumn{2}{|c|}{ Data Range Nilai } \\
\hline 1 & $<=39 \mathrm{~kg}$ \\
\hline 2 & $40-43 \mathrm{~kg}$ \\
\hline 3 & $44-47 \mathrm{~kg}$ \\
\hline 4 & $48-51 \mathrm{~kg}$ \\
\hline 5 & $52-55 \mathrm{~kg}$ \\
\hline
\end{tabular}

2. Penentuan Nilai Target

Penentuan nilai target per kriteria dan sub kriteria dari masing-masing cabang atletik ditentukan oleh pihak sekolah.

Tabel 7. Nilai Target Cabang Atletik Lari

\begin{tabular}{|l|c|c|c|c|c|}
\hline No. & $\begin{array}{c}\text { Krite } \\
\text { ria }\end{array}$ & $\begin{array}{c}\text { Kode Sub } \\
\text { Kriteria }\end{array}$ & $\begin{array}{c}\text { Sub } \\
\text { Kriteria }\end{array}$ & $\begin{array}{c}\text { Nilai } \\
\text { Tar }\end{array}$ & Faktor \\
\hline
\end{tabular}

\begin{tabular}{|c|c|c|c|c|c|}
\hline & & & & get & \\
\hline 1. & $\begin{array}{c}\text { Keku } \\
\text { atan }\end{array}$ & S001 & $\begin{array}{c}\text { Lari } 30 \\
\mathrm{~m}\end{array}$ & 4 & $\begin{array}{c}\text { Core } \\
\text { Factor }\end{array}$ \\
\hline \multirow[t]{3}{*}{2.} & \multirow{3}{*}{$\begin{array}{c}\text { Antro } \\
\text { pome } \\
\text { tri }\end{array}$} & S002 & IMT & 2 & $\begin{array}{l}\text { Core } \\
\text { Factor }\end{array}$ \\
\hline & & S003 & $\begin{array}{l}\text { Tinggi } \\
\text { Badan }\end{array}$ & 3 & $\begin{array}{c}\text { Secondary } \\
\text { Factor }\end{array}$ \\
\hline & & S004 & $\begin{array}{l}\text { Berat } \\
\text { Badan }\end{array}$ & 3 & $\begin{array}{c}\text { Secondary } \\
\text { Factor }\end{array}$ \\
\hline
\end{tabular}

Tabel 8. Nilai Target Cabang Atletik

\begin{tabular}{|c|c|c|c|c|c|}
\hline \multicolumn{6}{|c}{ Lompat } \\
\hline No. & $\begin{array}{c}\text { Krite } \\
\text { ria }\end{array}$ & $\begin{array}{c}\text { Kode Sub } \\
\text { Kriteria }\end{array}$ & $\begin{array}{c}\text { Sub } \\
\text { Kriteria }\end{array}$ & $\begin{array}{c}\text { Nilai } \\
\text { Target }\end{array}$ & Faktor \\
\hline 1. & $\begin{array}{c}\text { Keku } \\
\text { atan }\end{array}$ & S001 & Lari $30 \mathrm{~m}$ & 2 & $\begin{array}{c}\text { Core } \\
\text { Factor }\end{array}$ \\
\hline 2. & $\begin{array}{c}\text { Antro } \\
\text { pomet } \\
\text { ri }\end{array}$ & S005 & $\begin{array}{c}\text { Vertical } \\
\text { Jump }\end{array}$ & 3 & $\begin{array}{c}\text { Core } \\
\text { Factor }\end{array}$ \\
\cline { 3 - 6 } & & S003 & $\begin{array}{c}\text { Tinggi } \\
\text { Badan }\end{array}$ & 3 & $\begin{array}{c}\text { Seconda } \\
\text { ry } \\
\text { Factor }\end{array}$ \\
\cline { 3 - 6 } & & S004 & $\begin{array}{c}\text { Berat } \\
\text { Badan }\end{array}$ & 3 & $\begin{array}{c}\text { Seconda } \\
\text { ry } \\
\text { Factor }\end{array}$ \\
\hline
\end{tabular}

Tabel 9. Nilai Target Cabang Atletik Lempar

\begin{tabular}{|c|c|c|c|c|c|}
\hline No. & $\begin{array}{c}\text { Kriteri } \\
\text { a }\end{array}$ & $\begin{array}{c}\text { Kode Sub } \\
\text { Kriteria }\end{array}$ & $\begin{array}{c}\text { Sub } \\
\text { Kriteria }\end{array}$ & $\begin{array}{c}\text { Nilai } \\
\text { Target }\end{array}$ & Faktor \\
\hline 1. & $\begin{array}{c}\text { Kekuat } \\
\text { an }\end{array}$ & S006 & $\begin{array}{c}\text { Lempar } \\
\text { Ban }\end{array}$ & 4 & $\begin{array}{c}\text { Core } \\
\text { Factor }\end{array}$ \\
\hline 2. & $\begin{array}{c}\text { Antrop } \\
\text { ometri }\end{array}$ & S005 & $\begin{array}{c}\text { Vertical } \\
\text { Jump }\end{array}$ & 3 & $\begin{array}{c}\text { Core } \\
\text { Factor }\end{array}$ \\
\cline { 3 - 6 } & S003 & $\begin{array}{c}\text { Tinggi } \\
\text { Badan }\end{array}$ & 3 & $\begin{array}{c}\text { Second } \\
\text { ary } \\
\text { Factor }\end{array}$ \\
\cline { 3 - 6 } & & S004 & $\begin{array}{c}\text { Berat } \\
\text { Badan }\end{array}$ & 3 & $\begin{array}{c}\text { Second } \\
\text { ary } \\
\text { Factor }\end{array}$ \\
\hline
\end{tabular}

\section{Konversi Nilai Awal}

Nilai awal anggota yang sudah dimasukkan ke sistem selanjutnya akan dikonversikan sesuai dengan range nilai yang sudah ditentukan di awal.

Tabel 10. Hasil Konversi Nilai Cabang Atletik Lari

\begin{tabular}{|c|c|c|c|c|c|}
\hline \multirow{2}{*}{ No. } & \multirow{2}{*}{ Kode } & Kekuatan & \multicolumn{3}{|c|}{ Antropometri } \\
\cline { 3 - 6 } & Anggota & S001 & S002 & S003 & S004 \\
\hline 1. & A001 & 5 & 2 & 5 & 5 \\
\hline 2. & A002 & 2 & 2 & 4 & 4 \\
\hline 3. & A003 & 3 & 2 & 4 & 4 \\
\hline 4. & A004 & 5 & 2 & 5 & 5 \\
\hline 5. & A005 & 4 & 2 & 4 & 4 \\
\hline 6. & A006 & 4 & 2 & 4 & 4 \\
\hline 7. & A007 & 3 & 2 & 2 & 2 \\
\hline 8. & A008 & 3 & 2 & 3 & 3 \\
\hline 9. & A009 & 2 & 2 & 3 & 3 \\
\hline 10. & A010 & 2 & 2 & 3 & 3 \\
\hline 11. & A011 & 1 & 3 & 1 & 3 \\
\hline 12. & A012 & 1 & 2 & 2 & 2 \\
\hline 13. & A013 & 1 & 2 & 2 & 2 \\
\hline 14. & A014 & 1 & 2 & 2 & 3 \\
\hline
\end{tabular}




\begin{tabular}{|l|l|l|l|l|l|}
\hline 15. & $\mathrm{A} 015$ & 3 & 2 & 3 & 3 \\
\hline 16. & $\mathrm{A} 016$ & 2 & 1 & 2 & 2 \\
\hline 17. & $\mathrm{A} 017$ & 2 & 2 & 3 & 3 \\
\hline 18. & $\mathrm{A} 018$ & 3 & 2 & 3 & 3 \\
\hline 19. & $\mathrm{A} 019$ & 2 & 2 & 3 & 2 \\
\hline
\end{tabular}

Tabel 11. Hasil Konversi Nilai Cabang Atletik Lompat

\begin{tabular}{|c|c|c|c|c|c|}
\hline \multirow{2}{*}{ No. } & \multirow{2}{*}{$\begin{array}{c}\text { Kode } \\
\text { Anggota }\end{array}$} & Kekuatan & \multicolumn{3}{|c|}{ Antropometri } \\
\cline { 3 - 6 } & S001 & S005 & S003 & S004 \\
\hline 1. & A001 & 5 & 5 & 5 & 5 \\
\hline 2. & A002 & 2 & 4 & 4 & 4 \\
\hline 3. & A003 & 3 & 4 & 4 & 4 \\
\hline 4. & A004 & 5 & 4 & 5 & 5 \\
\hline 5. & A005 & 4 & 4 & 4 & 4 \\
\hline 6. & A006 & 4 & 4 & 4 & 4 \\
\hline 7. & A007 & 3 & 3 & 2 & 2 \\
\hline 8. & A008 & 3 & 3 & 3 & 3 \\
\hline 9. & A009 & 2 & 3 & 3 & 3 \\
\hline 10. & A010 & 2 & 3 & 3 & 3 \\
\hline 11. & A011 & 1 & 2 & 1 & 3 \\
\hline 12. & A012 & 1 & 2 & 2 & 2 \\
\hline 13. & A013 & 1 & 2 & 2 & 2 \\
\hline 14. & A014 & 1 & 3 & 2 & 3 \\
\hline 15. & A015 & 3 & 3 & 3 & 3 \\
\hline 16. & A016 & 2 & 2 & 2 & 2 \\
\hline 17. & A017 & 2 & 3 & 3 & 3 \\
\hline 18. & A018 & 3 & 3 & 3 & 3 \\
\hline 19. & A019 & 2 & 3 & 3 & 2 \\
\hline & & & & & \\
\hline
\end{tabular}

Tabel 12. Hasil Konversi Nilai Cabang Atletik Lempar

\begin{tabular}{|c|c|c|c|c|c|}
\hline \multirow{2}{*}{ No. } & \multirow{2}{*}{ Kode Anggota } & Kekuatan & \multicolumn{3}{|c|}{ Antropometri } \\
\cline { 3 - 6 } & & S006 & S005 & S003 & S004 \\
\hline 1. & A001 & 5 & 5 & 5 & 5 \\
\hline 2. & A002 & 4 & 4 & 4 & 4 \\
\hline 3. & A003 & 4 & 4 & 4 & 4 \\
\hline 4. & A004 & 5 & 4 & 5 & 5 \\
\hline 5. & A005 & 4 & 4 & 4 & 4 \\
\hline 6. & A006 & 4 & 4 & 4 & 4 \\
\hline 7. & A007 & 3 & 3 & 2 & 2 \\
\hline 8. & A008 & 4 & 3 & 3 & 3 \\
\hline 9. & A009 & 3 & 3 & 3 & 3 \\
\hline 10. & A010 & 2 & 3 & 3 & 3 \\
\hline 11. & A011 & 3 & 2 & 1 & 3 \\
\hline 12. & A012 & 1 & 2 & 2 & 2 \\
\hline 13. & A013 & 1 & 2 & 2 & 2 \\
\hline 14. & A014 & 3 & 3 & 2 & 3 \\
\hline 15. & A015 & 4 & 3 & 3 & 3 \\
\hline
\end{tabular}

\begin{tabular}{|l|l|l|l|l|l|}
\hline 16. & A016 & 1 & 2 & 2 & 2 \\
\hline 17. & A017 & 3 & 3 & 3 & 3 \\
\hline 18. & A018 & 3 & 3 & 3 & 3 \\
\hline 19. & A019 & 2 & 3 & 3 & 2 \\
\hline
\end{tabular}

4. Perhitungan Pemetaan Gap Kompetensi Perhitungan Gap kompetensi yaitu selisih antara nilai hasil konversi dari masingmasing anggota dengan nilai target per kriteria masing-masing cabang atletik. Rumus Gap = Nilai Anggota - Nilai Target.

Tabel 13. Pemetaan Gap Cabang Atletik Lari

\begin{tabular}{|c|c|c|c|c|c|}
\hline \multicolumn{7}{|c|}{ GAP (Nilai Anggota - Nilai Target) } \\
\hline No. & $\begin{array}{c}\text { Kode } \\
\text { Anggota }\end{array}$ & S001 & S002 & S003 & S004 \\
\hline 1. & A001 & 1 & 0 & 2 & 2 \\
\hline 2. & A002 & -2 & 0 & 1 & 1 \\
\hline 3. & A003 & -1 & 0 & 1 & 1 \\
\hline 4. & A004 & 1 & 0 & 2 & 2 \\
\hline 5. & A005 & 0 & 0 & 1 & 1 \\
\hline 6. & A006 & 0 & 0 & 1 & 1 \\
\hline 7. & A007 & -1 & 0 & -1 & -1 \\
\hline 8. & A008 & -1 & 0 & 0 & 0 \\
\hline 9. & A009 & -2 & 0 & 0 & 0 \\
\hline 10. & A010 & -2 & 0 & 0 & 0 \\
\hline 11. & A011 & -3 & 1 & -2 & 0 \\
\hline 12. & A012 & -3 & 0 & -1 & -1 \\
\hline 13. & A013 & -3 & 0 & -1 & -1 \\
\hline 14. & A014 & -3 & 0 & -1 & 0 \\
\hline 15. & A015 & -1 & 0 & 0 & 0 \\
\hline 16. & A016 & -2 & -1 & -1 & -1 \\
\hline 17. & A017 & -2 & 0 & 0 & 0 \\
\hline 18. & A018 & -1 & 0 & 0 & 0 \\
\hline 19. & A019 & -2 & 0 & 0 & -1 \\
\hline
\end{tabular}

Contoh perhitungan Gap cabang atletik lari sebagai berikut :

Mencari Gap kompetensi untuk kode anggota A001 :
GAP S001 $=5-4$$$
=1
$$
GAP S002 $=2-2$
$=0$
GAP S003 $=5-3$

$$
=2
$$
GAP S004 $=5-3$
$=2$

Tabel 14. Pemetaan Gap Cabang Atletik Lompat

\begin{tabular}{|c|c|c|c|c|c|}
\hline \multicolumn{6}{|c|}{ GAP (Nilai Anggota - Nilai Target) } \\
\hline No. & $\begin{array}{c}\text { Kode } \\
\text { Anggota }\end{array}$ & S001 & S005 & S003 & S004 \\
\hline 1. & A001 & 3 & 2 & 2 & 2 \\
\hline 2. & A002 & 0 & 1 & 1 & 1 \\
\hline 3. & A003 & 1 & 1 & 1 & 1 \\
\hline 4. & A004 & 3 & 1 & 2 & 2 \\
\hline 5. & A005 & 2 & 1 & 1 & 1 \\
\hline 6. & A006 & 2 & 1 & 1 & 1 \\
\hline
\end{tabular}




\begin{tabular}{|c|c|c|c|c|c|}
\hline 7. & A007 & 1 & 0 & -1 & -1 \\
\hline 8. & A008 & 1 & 0 & 0 & 0 \\
\hline 9. & A009 & 0 & 0 & 0 & 0 \\
\hline 10. & A010 & 0 & 0 & 0 & 0 \\
\hline 11. & A011 & -1 & -1 & -2 & 0 \\
\hline 12. & A012 & -1 & -1 & -1 & -1 \\
\hline 13. & A013 & -1 & -1 & -1 & -1 \\
\hline 14. & A014 & -1 & 0 & -1 & 0 \\
\hline 15. & A015 & 1 & 0 & 0 & 0 \\
\hline 16. & A016 & 0 & -1 & -1 & -1 \\
\hline 17. & A017 & 0 & 0 & 0 & 0 \\
\hline 18. & A018 & 1 & 0 & 0 & 0 \\
\hline 19. & A019 & 0 & 0 & 0 & -1 \\
\hline
\end{tabular}

Tabel 15. Pemetaan Gap Cabang Atletik Lempar

\begin{tabular}{|c|c|c|c|c|c|}
\hline \multicolumn{7}{|c|}{ GAP (Nilai Anggota - Nilai Target) } \\
\hline No. & $\begin{array}{c}\text { Kode } \\
\text { Anggota }\end{array}$ & S006 & S005 & S003 & S004 \\
\hline 1. & A001 & 1 & 2 & 2 & 2 \\
\hline 2. & A002 & 0 & 1 & 1 & 1 \\
\hline 3. & A003 & 0 & 1 & 1 & 1 \\
\hline 4. & A004 & 1 & 1 & 2 & 2 \\
\hline 5. & A005 & 0 & 1 & 1 & 1 \\
\hline 6. & A006 & 0 & 1 & 1 & 1 \\
\hline 7. & A007 & -1 & 0 & -1 & -1 \\
\hline 8. & A008 & 0 & 0 & 0 & 0 \\
\hline 9. & A009 & -1 & 0 & 0 & 0 \\
\hline 10. & A010 & -2 & 0 & 0 & 0 \\
\hline 11. & A011 & -1 & -1 & -2 & 0 \\
\hline 12. & A012 & -3 & -1 & -1 & -1 \\
\hline 13. & A013 & -3 & -1 & -1 & -1 \\
\hline 14. & A014 & -1 & 0 & -1 & 0 \\
\hline 15. & A015 & 0 & 0 & 0 & 0 \\
\hline 16. & A016 & -3 & -1 & -1 & -1 \\
\hline 17. & A017 & -1 & 0 & 0 & 0 \\
\hline 18. & A018 & -1 & 0 & 0 & 0 \\
\hline 19. & A019 & -2 & 0 & 0 & -1 \\
\hline
\end{tabular}

\section{Pembobotan}

Langkah berikutnya melakukan pencocokan hasil Gap dengan tabel bobot nilai Gap sesuai ketentuan pada tabel 16 .

Tabel 16. Bobot Nilai Gap

\begin{tabular}{|c|c|c|}
\hline Selisih & $\begin{array}{c}\text { Bobot } \\
\text { Nilai }\end{array}$ & Keterangan \\
\hline 0 & 5 & $\begin{array}{c}\text { Tidak ada selisih (kompetensi sesuai dengan } \\
\text { kebutuhan) }\end{array}$ \\
\hline 1 & 4,5 & Kompetensi individu kelebihan 1 level \\
\hline-1 & 4 & Kompetensi individu kekurangan 1 level \\
\hline 2 & 3,5 & Kompetensi individu kelebihan 2 level \\
\hline-2 & 3 & Kompetensi individu kekurangan 2 level \\
\hline 3 & 2,5 & Kompetensi individu kelebihan 3 level \\
\hline-3 & 2 & Kompetensi individu kekurangan 3 level \\
\hline 4 & 1,5 & Kompetensi individu kelebihan 4 level \\
\hline-4 & 1 & Kompetensi individu kekurangan 4 level \\
\hline
\end{tabular}

Hasil dari konversi Gap menjadi bobot sebagai berikut :
Tabel 17. Pembobotan Nilai Cabang Atletik Lari

\begin{tabular}{|c|c|c|c|c|c|}
\hline No. & $\begin{array}{c}\text { Kode } \\
\text { Anggota }\end{array}$ & S001 & S002 & S003 & S004 \\
\hline 1. & A001 & 4,5 & 5 & 3,5 & 3,5 \\
\hline 2. & $\mathrm{~A} 002$ & 3 & 5 & 4,5 & 4,5 \\
\hline 3. & $\mathrm{~A} 003$ & 4 & 5 & 4,5 & 4,5 \\
\hline 4. & $\mathrm{~A} 004$ & 4,5 & 5 & 3,5 & 3,5 \\
\hline 5. & $\mathrm{~A} 005$ & 5 & 5 & 4,5 & 4,5 \\
\hline 6. & $\mathrm{~A} 006$ & 5 & 5 & 4,5 & 4,5 \\
\hline 7. & $\mathrm{~A} 007$ & 4 & 5 & 4 & 4 \\
\hline 8. & $\mathrm{~A} 008$ & 4 & 5 & 5 & 5 \\
\hline 9. & $\mathrm{~A} 009$ & 3 & 5 & 5 & 5 \\
\hline 10. & $\mathrm{~A} 010$ & 3 & 5 & 5 & 5 \\
\hline 11. & $\mathrm{~A} 011$ & 2 & 4,5 & 3 & 5 \\
\hline 12. & $\mathrm{~A} 012$ & 2 & 5 & 4 & 4 \\
\hline 13. & $\mathrm{~A} 013$ & 2 & 5 & 4 & 4 \\
\hline 14. & $\mathrm{~A} 014$ & 2 & 5 & 4 & 5 \\
\hline 15. & $\mathrm{~A} 015$ & 4 & 5 & 5 & 5 \\
\hline 16. & $\mathrm{~A} 016$ & 3 & 4 & 4 & 4 \\
\hline 17. & $\mathrm{~A} 017$ & 3 & 5 & 5 & 5 \\
\hline 18. & $\mathrm{~A} 018$ & 4 & 5 & 5 & 5 \\
\hline 19. & $\mathrm{~A} 019$ & 3 & 5 & 5 & 4 \\
\hline
\end{tabular}

Tabel 18. Pembobotan Nilai Cabang Atletik Lompat

\begin{tabular}{|c|c|c|c|c|c|}
\hline No. & $\begin{array}{c}\text { Kode } \\
\text { Anggota }\end{array}$ & S001 & S005 & S003 & S004 \\
\hline 1. & $\mathrm{~A} 001$ & 2,5 & 3,5 & 3,5 & 3,5 \\
\hline 2. & $\mathrm{~A} 002$ & 5 & 4,5 & 4,5 & 4,5 \\
\hline 3. & $\mathrm{~A} 003$ & 4,5 & 4,5 & 4,5 & 4,5 \\
\hline 4. & $\mathrm{~A} 004$ & 2,5 & 4,5 & 3,5 & 3,5 \\
\hline 5. & $\mathrm{~A} 005$ & 3,5 & 4,5 & 4,5 & 4,5 \\
\hline 6. & $\mathrm{~A} 006$ & 3,5 & 4,5 & 4,5 & 4,5 \\
\hline 7. & $\mathrm{~A} 007$ & 4,5 & 5 & 4 & 4 \\
\hline 8. & $\mathrm{~A} 008$ & 4,5 & 5 & 5 & 5 \\
\hline 9. & $\mathrm{~A} 009$ & 5 & 5 & 5 & 5 \\
\hline 10. & $\mathrm{~A} 010$ & 5 & 5 & 5 & 5 \\
\hline 11. & $\mathrm{~A} 011$ & 4 & 4 & 3 & 5 \\
\hline 12. & $\mathrm{~A} 012$ & 4 & 4 & 4 & 4 \\
\hline 13. & $\mathrm{~A} 013$ & 4 & 4 & 4 & 4 \\
\hline 14. & $\mathrm{~A} 014$ & 4 & 5 & 4 & 5 \\
\hline 15. & $\mathrm{~A} 015$ & 4,5 & 5 & 5 & 5 \\
\hline 16. & $\mathrm{~A} 016$ & 5 & 4 & 4 & 4 \\
\hline 17. & $\mathrm{~A} 017$ & 5 & 5 & 5 & 5 \\
\hline 18. & $\mathrm{~A} 018$ & 4,5 & 5 & 5 & 5 \\
\hline 19. & $\mathrm{~A} 019$ & 5 & 5 & 5 & 4 \\
\hline
\end{tabular}

Tabel 19. Pembobotan Nilai Cabang Atletik Lempar

\begin{tabular}{|c|c|c|c|c|c|}
\hline No. & $\begin{array}{c}\text { Kode } \\
\text { Anggota }\end{array}$ & S006 & S005 & S003 & S004 \\
\hline 1. & $\mathrm{~A} 001$ & 4,5 & 3,5 & 3,5 & 3,5 \\
\hline 2. & $\mathrm{~A} 002$ & 5 & 4,5 & 4,5 & 4,5 \\
\hline 3. & $\mathrm{~A} 003$ & 5 & 4,5 & 4,5 & 4,5 \\
\hline 4. & $\mathrm{~A} 004$ & 4,5 & 4,5 & 3,5 & 3,5 \\
\hline 5. & $\mathrm{~A} 005$ & 5 & 4,5 & 4,5 & 4,5 \\
\hline 6. & $\mathrm{~A} 006$ & 5 & 4,5 & 4,5 & 4,5 \\
\hline 7. & $\mathrm{~A} 007$ & 4 & 5 & 4 & 4 \\
\hline 8. & $\mathrm{~A} 008$ & 5 & 5 & 5 & 5 \\
\hline 9. & $\mathrm{~A} 009$ & 4 & 5 & 5 & 5 \\
\hline 10. & $\mathrm{~A} 010$ & 3 & 5 & 5 & 5 \\
\hline 11. & $\mathrm{~A} 011$ & 4 & 4 & 3 & 5 \\
\hline 12. & $\mathrm{~A} 012$ & 2 & 4 & 4 & 4 \\
\hline 13. & $\mathrm{~A} 013$ & 2 & 4 & 4 & 4 \\
\hline 14. & $\mathrm{~A} 014$ & 4 & 5 & 4 & 5 \\
\hline 15. & $\mathrm{~A} 015$ & 5 & 5 & 5 & 5 \\
\hline 16. & $\mathrm{~A} 016$ & 2 & 4 & 4 & 4 \\
\hline 17. & $\mathrm{~A} 017$ & 4 & 5 & 5 & 5 \\
\hline 18. & $\mathrm{~A} 018$ & 4 & 5 & 5 & 5 \\
\hline 19. & $\mathrm{~A} 019$ & 3 & 5 & 5 & 4 \\
\hline
\end{tabular}

6. Perhitungan dan Pengelompokan Core 


\begin{tabular}{|c|c|c|c|c|c|c|c|c|c|c|c|}
\hline \multirow[b]{2}{*}{$\begin{array}{l}\mathrm{N} \\
\text { o. }\end{array}$} & \multirow[b]{2}{*}{$\begin{array}{l}\text { oode } \\
\text { Angg } \\
\text { ota }\end{array}$} & \multicolumn{4}{|c|}{ Kekuatan } & \multicolumn{6}{|c|}{ Antropometri } \\
\hline & & 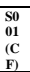 & $\begin{array}{c}\text { NC } \\
\text { C }\end{array}$ & $\underset{\mathrm{F}}{\mathrm{NS}}$ & $\begin{array}{l}\text { Nit } \\
\text { ait } \\
\text { Tot } \\
\text { al }\end{array}$ & $\begin{array}{l}\text { So } \\
\text { o2 } \\
\text { C. } \\
\text { F) }\end{array}$ & $\begin{array}{l}\mathbf{S o} 0 \\
\text { o3 } \\
\text { SFF } \\
\end{array}$ & $\begin{array}{l}\mathbf{S O} 0 \\
04 \\
\text { SF } \\
\end{array}$ & $\begin{array}{c}\mathrm{NC} \\
\mathbf{F} \\
\text { Nat }\end{array}$ & $\underset{\mathbf{F}}{N S}$ & $\begin{array}{l}\text { Nil } \\
\text { ai } \\
\text { Tot } \\
\text { al }\end{array}$ \\
\hline 1. & A001 & 4,5 & 4,5 & 0 & 2,7 & 5 & 3,5 & 3,5 & 5 & 3,5 & 4,4 \\
\hline 2. & A002 & 3 & 3 & 0 & 1,8 & 5 & 4,5 & 4,5 & 5 & 4.5 & 4.8 \\
\hline 3. & A003 & 4 & 4 & 0 & 2,4 & 5 & 4.5 & 4.5 & 5 & 4,5 & 4.8 \\
\hline 4. & A004 & 4.5 & 4.5 & 0 & 2.7 & 5 & 3,5 & 3.5 & 5 & 3,5 & 4,4 \\
\hline 5. & A005 & 5 & 5 & 0 & 3 & 5 & 4.5 & 4.5 & 5 & 4,5 & 4,8 \\
\hline 6. & A006 & 5 & 5 & 0 & 3 & 5 & 4.5 & 4,5 & 5 & 4,5 & 4,8 \\
\hline 7. & A007 & 4 & 4 & 0 & 2,4 & 5 & 4 & 4 & 5 & 4 & 4,6 \\
\hline 8. & A008 & 4 & 4 & 0 & 2,4 & 5 & 5 & 5 & 5 & 5 & 5 \\
\hline 9. & A009 & 3 & 3 & 0 & 1,8 & 5 & 5 & 5 & 5 & 5 & 5 \\
\hline 10 & A010 & 3 & 3 & 0 & 1,8 & 5 & 5 & 5 & 5 & 5 & 5 \\
\hline 11 & A011 & 2 & 2 & 0 & 1,2 & 4,5 & 3 & 5 & 4.5 & 4 & 4.3 \\
\hline 12 & A012 & 2 & 2 & 0 & 1,2 & 5 & 4 & 4 & 5 & 4 & 4,6 \\
\hline 13 & A013 & 2 & 2 & 0 & 1,2 & 5 & 4 & 4 & 5 & 4 & 4,6 \\
\hline 14 & A014 & 2 & 2 & 0 & 1,2 & 5 & 4 & 5 & 5 & 4.5 & 4.8 \\
\hline 15 & A015 & 4 & 4 & 0 & 2,4 & 5 & 5 & 5 & 5 & 5 & 5 \\
\hline 16 & A016 & 3 & 3 & 0 & 1,8 & 4 & 4 & 4 & 4 & 4 & 4 \\
\hline 17 & A017 & 3 & 3 & 0 & 1,8 & 5 & 5 & 5 & 5 & 5 & 5 \\
\hline 18 & A018 & 4 & 4 & 0 & 2,4 & 5 & 5 & 5 & 5 & 5 & 5 \\
\hline 19 & A019 & 3 & 3 & 0 & 1,8 & 5 & 5 & 4 & 5 & 4,5 & 4,8 \\
\hline
\end{tabular}

Factor dan Secondary Factor

Tabel 20. Perhitungan CF \& SF Cabang

$$
\text { Atletik Lari }
$$

Contoh perhitungan $\mathrm{CF} \& \mathrm{SF}$ cabang atletik lari sebagai berikut :

Mencari NCF, NSF, dan Nilai Total untuk kode anggota A001 :

1. Nilai NCF, NSF, dan Nilai Total Aspek Kekuatan

$$
\begin{aligned}
\mathrm{NCF} & =\mathrm{NC} / \mathrm{IC} \\
& =4,5 / 1 \\
& =4,5 \\
\mathrm{NSF} & =\mathrm{NS} / \mathrm{IS} \\
& =0 / 0 \\
& =0
\end{aligned}
$$

Nilai Total dari masing-masing aspek setiap alternatif ditentukan $60 \%$ untuk core factor dan $40 \%$ untuk secondary factor.

Nilai Total

$=(60 / 100 \times \mathrm{NCF})+(40 / 100 \times \mathrm{NSF})$

$=(60 / 100 \times 4,5)+(40 / 100 \times 0)$

$=2,7$

2. Nilai NCF, NSF, dan Nilai Total Aspek Antropometri

$$
\begin{aligned}
\mathrm{NCS} & =\mathrm{NC} / \mathrm{IC} \\
& =5 / 1 \\
& =5 \\
\mathrm{NSF} & =\mathrm{NS} / \mathrm{IS} \\
& =((3,5+3,5)) / 2 \\
& =3,5
\end{aligned}
$$

\begin{tabular}{|c|c|c|c|c|c|c|c|c|c|c|c|}
\hline \multirow[b]{2}{*}{$\begin{array}{l}\text { o } \\
\text {. }\end{array}$} & \multirow[b]{2}{*}{$\begin{array}{l}\text { Ko } \\
\text { de } \\
\text { An } \\
\text { gg } \\
\text { ota }\end{array}$} & \multicolumn{5}{|c|}{ Kekuatan } & \multicolumn{5}{|c|}{ Antropometri } \\
\hline & & $\begin{array}{l}\mathbf{S} \\
\mathbf{0} \\
\mathbf{0} \\
\mathbf{1} \\
( \\
\mathbf{C} \\
\mathbf{F} \\
) \\
\end{array}$ & $\begin{array}{l}\text { S } \\
\mathbf{0} \\
\mathbf{0} \\
\mathbf{5} \\
( \\
\mathbf{C} \\
\mathbf{F} \\
\text { ) }\end{array}$ & $\begin{array}{l}\mathbf{N} \\
\mathbf{C} \\
\mathbf{F}\end{array}$ & $\begin{array}{l}\mathbf{N} \\
\mathbf{S} \\
\mathbf{F}\end{array}$ & $\begin{array}{c}\mathbf{N} \\
\text { il } \\
\text { ai } \\
\mathbf{T} \\
\text { ot } \\
\text { al }\end{array}$ & $\begin{array}{l}\mathbf{S} \\
\mathbf{0} \\
\mathbf{0} \\
\mathbf{3} \\
( \\
\mathbf{S} \\
\mathbf{F} \\
) \\
\end{array}$ & $\begin{array}{l}S \\
\text { 0 } \\
\text { 0 } \\
4 \\
( \\
\text { S } \\
\text { F } \\
\text { ) } \\
\end{array}$ & $\begin{array}{l}\mathbf{N} \\
\mathbf{C} \\
\mathbf{F}\end{array}$ & $\begin{array}{l}\mathbf{N} \\
\mathbf{S} \\
\mathbf{F}\end{array}$ & $\begin{array}{c}\mathbf{N} \\
\text { il } \\
\text { ai } \\
\mathbf{T} \\
\text { ot } \\
\text { al }\end{array}$ \\
\hline 1 & $\begin{array}{c}\text { A0 } \\
01\end{array}$ & $\begin{array}{l}2, \\
5\end{array}$ & $\begin{array}{c}3, \\
5\end{array}$ & 3 & 0 & $\begin{array}{l}1, \\
8\end{array}$ & $\begin{array}{l}3, \\
5\end{array}$ & $\begin{array}{l}3, \\
5\end{array}$ & 0 & $\begin{array}{l}3 \\
5 \\
5\end{array}$ & $\begin{array}{l}1, \\
4\end{array}$ \\
\hline $\begin{array}{l}2 \\
.\end{array}$ & $\begin{array}{l}\mathrm{A} 0 \\
02\end{array}$ & 5 & $\begin{array}{l}4, \\
5\end{array}$ & $\begin{array}{l}4, \\
7 \\
5\end{array}$ & 0 & $\begin{array}{c}2, \\
8 \\
5\end{array}$ & $\begin{array}{l}4, \\
5\end{array}$ & $\begin{array}{l}4, \\
5\end{array}$ & 0 & $\begin{array}{l}4 \\
5\end{array}$ & $\begin{array}{l}1, \\
8\end{array}$ \\
\hline 3 & $\begin{array}{l}\mathrm{A} 0 \\
03\end{array}$ & $\begin{array}{l}4, \\
5\end{array}$ & $\begin{array}{l}4, \\
5\end{array}$ & $\begin{array}{l}4, \\
5\end{array}$ & 0 & $\begin{array}{l}2, \\
7\end{array}$ & $\begin{array}{c}4, \\
5\end{array}$ & $\begin{array}{c}4, \\
5\end{array}$ & 0 & $\begin{array}{l}4 \\
5\end{array}$ & $\begin{array}{l}1, \\
8\end{array}$ \\
\hline $\begin{array}{l}4 \\
.\end{array}$ & $\begin{array}{l}\mathrm{A} 0 \\
04\end{array}$ & $\begin{array}{l}2, \\
5\end{array}$ & $\begin{array}{l}4, \\
5\end{array}$ & $\begin{array}{l}3 \\
5\end{array}$ & 0 & $\begin{array}{c}2, \\
1\end{array}$ & $\begin{array}{l}3, \\
5\end{array}$ & $\begin{array}{c}3, \\
5\end{array}$ & 0 & $\begin{array}{l}3 \\
5 \\
\text { ' }\end{array}$ & $\begin{array}{l}1, \\
4\end{array}$ \\
\hline 5 & $\begin{array}{l}\mathrm{A} 0 \\
05\end{array}$ & $\begin{array}{l}3, \\
5\end{array}$ & $\begin{array}{c}4, \\
5\end{array}$ & 4 & 0 & $\begin{array}{c}2 \\
4\end{array}$ & $\begin{array}{l}4, \\
5\end{array}$ & $\begin{array}{l}4, \\
5\end{array}$ & 0 & $\begin{array}{l}4 \\
5\end{array}$ & $\begin{array}{l}1, \\
8\end{array}$ \\
\hline 6 & $\begin{array}{l}\text { A0 } \\
06\end{array}$ & $\begin{array}{l}3 \\
5\end{array}$ & $\begin{array}{c}4, \\
5\end{array}$ & 4 & 0 & $\begin{array}{c}2 \\
4\end{array}$ & $\begin{array}{l}4, \\
5\end{array}$ & $\begin{array}{c}4, \\
5\end{array}$ & 0 & $\begin{array}{l}4 \\
5\end{array}$ & $\begin{array}{l}1, \\
8\end{array}$ \\
\hline 7 & $\begin{array}{l}\text { A0 } \\
07\end{array}$ & $\begin{array}{c}4 \\
5\end{array}$ & 5 & $\begin{array}{l}4 \\
7 \\
5\end{array}$ & 0 & $\begin{array}{l}2 \\
8 \\
5\end{array}$ & 4 & 4 & 0 & 4 & $\begin{array}{l}1, \\
6\end{array}$ \\
\hline 8 & $\begin{array}{c}\text { A0 } \\
08\end{array}$ & $\begin{array}{l}4, \\
5\end{array}$ & 5 & $\begin{array}{l}4 \\
7 \\
5\end{array}$ & 0 & $\begin{array}{c}2, \\
8 \\
5\end{array}$ & 5 & 5 & 0 & 5 & 2 \\
\hline 9 & $\begin{array}{l}\text { A0 } \\
09\end{array}$ & 5 & 5 & 5 & 0 & 3 & 5 & 5 & 0 & 5 & 2 \\
\hline $\begin{array}{l}1 \\
0\end{array}$ & $\begin{array}{c}\text { A0 } \\
10\end{array}$ & 5 & 5 & 5 & 0 & 3 & 5 & 5 & 0 & 5 & 2 \\
\hline $\begin{array}{l}1 \\
1\end{array}$ & $\begin{array}{c}\mathrm{A} 0 \\
11\end{array}$ & 4 & 4 & 4 & 0 & $\begin{array}{c}2 \\
4\end{array}$ & 3 & 5 & 0 & 4 & $\begin{array}{l}1, \\
6\end{array}$ \\
\hline $\begin{array}{l}1 \\
2\end{array}$ & $\begin{array}{l}\text { A0 } \\
12\end{array}$ & 4 & 4 & 4 & 0 & $\begin{array}{c}2 \\
4\end{array}$ & 4 & 4 & 0 & 4 & $\begin{array}{l}1, \\
6\end{array}$ \\
\hline
\end{tabular}

Nilai Total dari masing-masing aspek setiap alternatif ditentukan $60 \%$ untuk core factor dan $40 \%$ untuk secondary factor.

Nilai Total

$=(60 / 100 \times \mathrm{NCF})+(40 / 100 \times \mathrm{NSF})$

$=(60 / 100 \times 5)+(40 / 100 \times 3,5)$

$=4,4$

Tabel 21. Perhitungan CF \& SF Cabang Atletik Lompat 


\begin{tabular}{|c|c|c|c|c|c|c|c|c|c|c|c|}
\hline $\begin{array}{l}1 \\
3\end{array}$ & $\begin{array}{l}\text { A0 } \\
13\end{array}$ & 4 & 4 & 4 & 0 & $\begin{array}{c}2 \\
4\end{array}$ & 4 & 4 & 0 & 4 & $\begin{array}{l}1, \\
6\end{array}$ \\
\hline $\begin{array}{l}1 \\
4\end{array}$ & $\begin{array}{c}\text { A0 } \\
14\end{array}$ & 4 & 5 & $\begin{array}{l}4, \\
5\end{array}$ & 0 & $\begin{array}{l}2, \\
7\end{array}$ & 4 & 5 & 0 & $\begin{array}{l}4 \\
5 \\
5\end{array}$ & $\begin{array}{l}1, \\
8\end{array}$ \\
\hline $\begin{array}{l}1 \\
5\end{array}$ & $\begin{array}{l}\mathrm{A} 0 \\
15\end{array}$ & $\begin{array}{l}4 \\
5\end{array}$ & 5 & $\begin{array}{l}4, \\
7 \\
5 \\
\end{array}$ & 0 & $\begin{array}{l}2, \\
8 \\
5\end{array}$ & 5 & 5 & 0 & 5 & 2 \\
\hline $\begin{array}{l}1 \\
6\end{array}$ & $\begin{array}{l}\mathrm{A} 0 \\
16\end{array}$ & 5 & 4 & $\begin{array}{c}4 \\
5\end{array}$ & 0 & $\begin{array}{l}2, \\
7\end{array}$ & 4 & 4 & 0 & 4 & $\begin{array}{l}1, \\
6\end{array}$ \\
\hline $\begin{array}{l}1 \\
7\end{array}$ & $\begin{array}{l}\mathrm{A} 0 \\
17\end{array}$ & 5 & 5 & 5 & 0 & 3 & 5 & 5 & 0 & 5 & 2 \\
\hline $\begin{array}{l}1 \\
8\end{array}$ & $\begin{array}{c}\mathrm{A} 0 \\
18\end{array}$ & $\begin{array}{c}4, \\
5\end{array}$ & 5 & $\begin{array}{l}4, \\
7 \\
5\end{array}$ & 0 & $\begin{array}{c}2, \\
8 \\
5\end{array}$ & 5 & 5 & 0 & 5 & 2 \\
\hline $\begin{array}{l}1 \\
9\end{array}$ & $\begin{array}{c}\text { A0 } \\
19\end{array}$ & 5 & 5 & 5 & 0 & 3 & 5 & 4 & 0 & $\begin{array}{l}4 \\
5\end{array}$ & $\begin{array}{l}1, \\
8\end{array}$ \\
\hline
\end{tabular}

Tabel 22. Perhitungan CF \& SF Cabang Atletik Lempar

\begin{tabular}{|c|c|c|c|c|c|c|c|c|c|c|c|}
\hline \multirow[b]{2}{*}{$\begin{array}{l}\mathbf{N} \\
\mathbf{o} \\
.\end{array}$} & \multirow[b]{2}{*}{$\begin{array}{c}\text { Ko } \\
\text { de } \\
\text { An } \\
\text { gg } \\
\text { ot } \\
\text { a }\end{array}$} & \multicolumn{5}{|c|}{ Kekuatan } & \multicolumn{5}{|c|}{ Antropometri } \\
\hline & & $\begin{array}{l}\mathbf{S} \\
\mathbf{0} \\
\mathbf{0} \\
\mathbf{6} \\
( \\
\mathbf{C} \\
\mathbf{F} \\
)\end{array}$ & $\begin{array}{l}\text { S } \\
\text { 0 } \\
\mathbf{0} \\
\mathbf{5} \\
( \\
\mathbf{C} \\
\mathbf{F} \\
\text { ) }\end{array}$ & $\begin{array}{l}\mathbf{N} \\
\mathbf{C} \\
\mathbf{F}\end{array}$ & $\begin{array}{l}\mathbf{N} \\
\mathbf{S} \\
\mathbf{F}\end{array}$ & $\begin{array}{l}\mathbf{N} \\
\text { il } \\
\text { ai } \\
\mathbf{T} \\
\text { ot } \\
\text { al }\end{array}$ & $\begin{array}{l}\mathbf{S} \\
\mathbf{0} \\
\mathbf{0} \\
\mathbf{3} \\
( \\
\mathbf{S} \\
\mathbf{F} \\
)\end{array}$ & $\begin{array}{l} \\
\mathbf{0} \\
\mathbf{0} \\
\mathbf{4} \\
( \\
\mathbf{S} \\
\mathbf{F} \\
)\end{array}$ & $\begin{array}{l}\mathbf{N} \\
\mathbf{C} \\
\mathbf{F}\end{array}$ & $\begin{array}{l}\mathbf{N} \\
\mathbf{S} \\
\mathbf{F}\end{array}$ & $\begin{array}{l}\mathbf{N} \\
\text { il } \\
\text { ai } \\
\mathbf{T} \\
\text { ot } \\
\text { al }\end{array}$ \\
\hline $\begin{array}{l}1 \\
.\end{array}$ & $\begin{array}{l}\text { A0 } \\
01\end{array}$ & $\begin{array}{l}4 \\
5\end{array}$ & $\begin{array}{l}3, \\
5\end{array}$ & 4 & 0 & $\begin{array}{l}2, \\
4\end{array}$ & $\begin{array}{l}3, \\
5\end{array}$ & $\begin{array}{l}3 \\
5\end{array}$ & 0 & $\begin{array}{l}3 \\
5 \\
5\end{array}$ & $\begin{array}{l}1, \\
4\end{array}$ \\
\hline $\begin{array}{l}2 \\
.\end{array}$ & $\begin{array}{l}\text { A0 } \\
02\end{array}$ & 5 & $\begin{array}{c}4, \\
5\end{array}$ & $\begin{array}{l}4, \\
7 \\
5\end{array}$ & 0 & $\begin{array}{l}2, \\
8 \\
5\end{array}$ & $\begin{array}{c}4, \\
5\end{array}$ & $\begin{array}{l}4 \\
5\end{array}$ & 0 & $\begin{array}{l}4 \\
5 \\
5\end{array}$ & $\begin{array}{l}1, \\
8\end{array}$ \\
\hline $\begin{array}{l}3 \\
.\end{array}$ & $\begin{array}{l}\text { A0 } \\
03\end{array}$ & 5 & $\begin{array}{c}4, \\
5\end{array}$ & $\begin{array}{l}4, \\
7 \\
5\end{array}$ & 0 & $\begin{array}{l}2, \\
8 \\
5\end{array}$ & $\begin{array}{l}4 \\
5\end{array}$ & $\begin{array}{l}4, \\
5\end{array}$ & 0 & $\begin{array}{l}4 \\
5 \\
5\end{array}$ & $\begin{array}{l}1, \\
8\end{array}$ \\
\hline $\begin{array}{l}4 \\
.\end{array}$ & $\begin{array}{l}\text { A0 } \\
04\end{array}$ & $\begin{array}{l}4, \\
5\end{array}$ & $\begin{array}{l}4, \\
5\end{array}$ & $\begin{array}{c}4, \\
5\end{array}$ & 0 & $\begin{array}{l}2, \\
7\end{array}$ & $\begin{array}{l}3, \\
5\end{array}$ & $\begin{array}{l}3 \\
5\end{array}$ & 0 & $\begin{array}{l}3 \\
5 \\
5\end{array}$ & $\begin{array}{l}1, \\
4\end{array}$ \\
\hline $\begin{array}{l}5 \\
.\end{array}$ & $\begin{array}{l}\text { A0 } \\
05\end{array}$ & 5 & $\begin{array}{c}4, \\
5\end{array}$ & $\begin{array}{l}4, \\
7 \\
5\end{array}$ & 0 & $\begin{array}{l}2, \\
8 \\
5\end{array}$ & $\begin{array}{l}4 \\
5\end{array}$ & $\begin{array}{l}4 \\
5\end{array}$ & 0 & $\begin{array}{l}4 \\
5 \\
5\end{array}$ & $\begin{array}{l}1, \\
8\end{array}$ \\
\hline 6 & $\begin{array}{l}\text { A0 } \\
06\end{array}$ & 5 & $\begin{array}{c}4, \\
5\end{array}$ & $\begin{array}{l}4, \\
7 \\
5\end{array}$ & 0 & $\begin{array}{l}2, \\
8 \\
5\end{array}$ & $\begin{array}{l}4, \\
5\end{array}$ & $\begin{array}{l}4, \\
5\end{array}$ & 0 & $\begin{array}{l}4 \\
5 \\
5\end{array}$ & $\begin{array}{l}1, \\
8\end{array}$ \\
\hline 7 & $\begin{array}{l}\text { A0 } \\
07\end{array}$ & 4 & 5 & $\begin{array}{c}4, \\
5\end{array}$ & 0 & $\begin{array}{l}2, \\
7\end{array}$ & 4 & 4 & 0 & 4 & $\begin{array}{l}1, \\
6\end{array}$ \\
\hline 8 & $\begin{array}{l}\text { A0 } \\
08 \\
\end{array}$ & 5 & 5 & 5 & 0 & 3 & 5 & 5 & 0 & 5 & 2 \\
\hline 9 & $\begin{array}{l}\text { A0 } \\
09 \\
\end{array}$ & 4 & 5 & $\begin{array}{l}4, \\
5 \\
\end{array}$ & 0 & $\begin{array}{l}2, \\
7 \\
\end{array}$ & 5 & 5 & 0 & 5 & 2 \\
\hline $\begin{array}{l}1 \\
0\end{array}$ & $\begin{array}{l}\text { A0 } \\
10\end{array}$ & 3 & 5 & 4 & 0 & $\begin{array}{l}2 \\
4\end{array}$ & 5 & 5 & 0 & 5 & 2 \\
\hline $\begin{array}{l}1 \\
1\end{array}$ & $\begin{array}{c}\text { A0 } \\
11\end{array}$ & 4 & 4 & 4 & 0 & $\begin{array}{l}2 \\
4\end{array}$ & 3 & 5 & 0 & 4 & $\begin{array}{l}1, \\
6\end{array}$ \\
\hline $\begin{array}{l}1 \\
2\end{array}$ & $\begin{array}{l}\text { A0 } \\
12\end{array}$ & 2 & 4 & 3 & 0 & $\begin{array}{l}1, \\
8\end{array}$ & 4 & 4 & 0 & 4 & $\begin{array}{l}1, \\
6\end{array}$ \\
\hline 1 & A0 & 2 & 4 & 3 & 0 & 1, & 4 & 4 & 0 & 4 & 1 , \\
\hline
\end{tabular}

\begin{tabular}{|c|c|c|c|c|c|c|c|c|c|c|c|}
\hline 3 & 13 & & & & & 8 & & & & & 6 \\
\hline $\begin{array}{l}1 \\
4\end{array}$ & $\begin{array}{c}\text { A0 } \\
14\end{array}$ & 4 & 5 & $\begin{array}{c}4, \\
5\end{array}$ & 0 & $\begin{array}{l}2, \\
7\end{array}$ & 4 & 5 & 0 & $\begin{array}{l}4 \\
5\end{array}$ & $\begin{array}{l}1, \\
8\end{array}$ \\
\hline $\begin{array}{l}1 \\
5\end{array}$ & $\begin{array}{l}\text { A0 } \\
15\end{array}$ & 5 & 5 & 5 & 0 & 3 & 5 & 5 & 0 & 5 & 2 \\
\hline $\begin{array}{l}1 \\
6\end{array}$ & $\begin{array}{c}\text { A0 } \\
16\end{array}$ & 2 & 4 & 3 & 0 & $\begin{array}{l}1, \\
8\end{array}$ & 4 & 4 & 0 & 4 & $\begin{array}{l}1, \\
6\end{array}$ \\
\hline $\begin{array}{l}1 \\
7\end{array}$ & $\begin{array}{l}\text { A0 } \\
17\end{array}$ & 4 & 5 & $\begin{array}{c}4, \\
5\end{array}$ & 0 & $\begin{array}{l}2, \\
7\end{array}$ & 5 & 5 & 0 & 5 & 2 \\
\hline $\begin{array}{l}1 \\
8\end{array}$ & $\begin{array}{c}\text { A0 } \\
18\end{array}$ & 4 & 5 & $\begin{array}{c}4, \\
5\end{array}$ & 0 & $\begin{array}{l}2, \\
7\end{array}$ & 5 & 5 & 0 & 5 & 2 \\
\hline $\begin{array}{l}1 \\
9\end{array}$ & $\begin{array}{c}\text { A0 } \\
19\end{array}$ & 3 & 5 & 4 & 0 & $\begin{array}{l}2, \\
4\end{array}$ & 5 & 4 & 0 & 4 & $\begin{array}{l}1, \\
8\end{array}$ \\
\hline
\end{tabular}

\section{Perhitungan Hasil Akhir}

Untuk mendapatkan hasil akhir dilakukan perhitungan hasil akhir dari nilai total masingmasing aspek ditentukan 80\% untuk aspek kekuatan dan $20 \%$ untuk aspek antropometri.

Tabel 23. Perhitungan Hasil Akhir Cabang Atletik Lari

\begin{tabular}{|c|c|c|c|c|}
\hline \multirow{2}{*}{$\begin{array}{c}\text { No } \\
\text {. }\end{array}$} & \multirow{2}{*}{$\begin{array}{c}\text { Kode } \\
\text { Anggo } \\
\text { ta }\end{array}$} & $\begin{array}{c}\text { Kekuat } \\
\text { an }\end{array}$ & $\begin{array}{c}\text { Antropome } \\
\text { tri }\end{array}$ & \multirow{2}{*}{$\begin{array}{c}\text { Hasi } \\
\text { l } \\
\text { Akhi } \\
\text { r } \\
\end{array}$} \\
\hline & & $\begin{array}{l}\text { Nilai } \\
\text { Total }\end{array}$ & Nilai Total & \\
\hline 1. & A001 & 2,7 & 4,4 & 3,04 \\
\hline 2. & A002 & 1,8 & 4,8 & 2,4 \\
\hline 3. & $\mathrm{~A} 003$ & 2,4 & 4,8 & 2,88 \\
\hline 4. & A004 & 2,7 & 4,4 & 3,04 \\
\hline 5. & A005 & 3 & 4,8 & 3,36 \\
\hline 6. & A006 & 3 & 4,8 & 3,36 \\
\hline 7. & A007 & 2,4 & 4,6 & 2,84 \\
\hline 8. & A008 & 2,4 & 5 & 2,92 \\
\hline 9. & A009 & 1,8 & 5 & 2,44 \\
\hline 10. & $\mathrm{~A} 010$ & 1,8 & 5 & 2,44 \\
\hline 11. & A011 & 1,2 & 4,3 & 1,82 \\
\hline 12. & $\mathrm{~A} 012$ & 1,2 & 4,6 & 1,88 \\
\hline 13. & $\mathrm{~A} 013$ & 1,2 & 4,6 & 1,88 \\
\hline 14. & $\mathrm{~A} 014$ & 1,2 & 4,8 & 1,92 \\
\hline 15. & $\mathrm{~A} 015$ & 2,4 & 5 & 2,92 \\
\hline 16. & A016 & 1,8 & 4 & 2,24 \\
\hline 17. & $\mathrm{~A} 017$ & 1,8 & 5 & 2,44 \\
\hline 18. & $\mathrm{~A} 018$ & 2,4 & 5 & 2,92 \\
\hline 19. & A019 & 1,8 & 4,8 & 2,4 \\
\hline
\end{tabular}

Contoh perhitungan Hasil Akhir cabang atletik lari sebagai berikut :

Mencari Hasil Akhir untuk kode anggota A001 : 
Hasil Akhir

$=(80 / 100 \times$ Nilai Total Kekuatan $)$

$+(20 / 100 \times$ Nilai Total Antropometri)

$=(80 / 100 \times 2,7)+(20 / 100 \times 4,4)$

$=3,04$

Tabel 24. Perhitungan Hasil Akhir Cabang Atletik Lompat

\begin{tabular}{|c|c|c|c|c|}
\hline \multirow{2}{*}{$\begin{array}{c}\text { No } \\
\text { • }\end{array}$} & \multirow{2}{*}{$\begin{array}{c}\text { Kode } \\
\text { Anggo } \\
\text { ta }\end{array}$} & $\begin{array}{c}\text { Kekuat } \\
\text { an }\end{array}$ & $\begin{array}{c}\text { Antropome } \\
\text { tri }\end{array}$ & \multirow{2}{*}{$\begin{array}{c}\text { Hasi } \\
\text { l } \\
\text { Akhi } \\
\text { r }\end{array}$} \\
\hline & & $\begin{array}{l}\text { Nilai } \\
\text { Total }\end{array}$ & Nilai Total & \\
\hline 1. & A001 & 1,8 & 1,4 & 1,72 \\
\hline 2. & A002 & 2,85 & 1,8 & 2,64 \\
\hline 3. & A003 & 2,7 & 1,8 & 2,52 \\
\hline 4. & A004 & 2,1 & 1,4 & 1,96 \\
\hline 5. & A005 & 2,4 & 1,8 & 2,28 \\
\hline 6. & A006 & 2,4 & 1,8 & 2,28 \\
\hline 7. & A007 & 2,85 & 1,6 & 2,6 \\
\hline 8. & A008 & 2,85 & 2 & 2,68 \\
\hline 9. & A009 & 3 & 2 & 2,8 \\
\hline 10. & A010 & 3 & 2 & 2,8 \\
\hline 11. & A011 & 2,4 & 1,6 & 2,24 \\
\hline 12. & A012 & 2,4 & 1,6 & 2,24 \\
\hline 13. & $\mathrm{~A} 013$ & 2,4 & 1,6 & 2,24 \\
\hline 14. & $\mathrm{~A} 014$ & 2,7 & 1,8 & 2,52 \\
\hline 15. & $\mathrm{~A} 015$ & 2,85 & 2 & 2,68 \\
\hline 16. & A016 & 2,7 & 1,6 & 2,48 \\
\hline 17. & $\mathrm{~A} 017$ & 3 & 2 & 2,8 \\
\hline 18. & A018 & 2,85 & 2 & 2,68 \\
\hline 19. & A019 & 3 & 1,8 & 2,76 \\
\hline
\end{tabular}

Tabel 25. Perhitungan Hasil Akhir Cabang Atletik Lempar

\begin{tabular}{|c|c|c|c|c|}
\hline \multirow{2}{*}{ No. } & \multirow{2}{*}{$\begin{array}{l}\text { Kode } \\
\text { Anggota }\end{array}$} & \multirow{2}{*}{$\begin{array}{c}\text { Kekuatan } \\
\text { Nilai Total }\end{array}$} & \multirow{2}{*}{$\begin{array}{c}\text { Antropometri } \\
\text { Nilai Total } \\
\end{array}$} & \multirow{2}{*}{$\begin{array}{r}\text { Hasil } \\
\text { Akhir }\end{array}$} \\
\hline & & & & \\
\hline 1. & A001 & 2,4 & 1,4 & 2,2 \\
\hline 2. & A002 & 2,85 & 1,8 & 2,64 \\
\hline 3. & A003 & 2,85 & 1,8 & 2,64 \\
\hline 4. & A004 & 2,7 & 1,4 & 2,44 \\
\hline 5. & $\mathrm{~A} 005$ & 2,85 & 1,8 & 2,64 \\
\hline 6. & A006 & 2,85 & 1,8 & 2,64 \\
\hline 7. & $\mathrm{~A} 007$ & 2,7 & 1,6 & 2,48 \\
\hline 8. & A008 & 3 & 2 & 2,8 \\
\hline 9. & A009 & 2,7 & 2 & 2,56 \\
\hline 10. & A010 & 2,4 & 2 & 2,32 \\
\hline 11. & A011 & 2,4 & 1,6 & 2,24 \\
\hline 12. & A012 & 1,8 & 1,6 & 1,76 \\
\hline 13. & A013 & 1,8 & 1,6 & 1,76 \\
\hline 14. & A014 & 2,7 & 1,8 & 2,52 \\
\hline 15. & A015 & 3 & 2 & 2,8 \\
\hline 16. & A016 & 1,8 & 1,6 & 1,76 \\
\hline 17. & A017 & 2,7 & 2 & 2,56 \\
\hline
\end{tabular}

\begin{tabular}{|c|c|c|c|c|}
\hline 18. & A018 & 2,7 & 2 & 2,56 \\
\hline 19. & A019 & 2,4 & 1,8 & 2,28 \\
\hline
\end{tabular}

4. Penentuan Ekstrakurikuler Atletik

Penentuan ekstrakurikuler atletik siswa ditentukan berdasarkan hasil akhir tertinggi dari masing-masing cabang atletik yang nantinya dapat digunakan sebagai penunjang keputusan dalam menentukan ekstrakurikuler atletik siswa. Berikut hasil penentuan ekstrakurikuler atletik siswa dapat dilihat pada tabel 26

Tabel 26. Penentuan Ekstrakurikuler Atletik

\begin{tabular}{|c|c|c|c|c|c|}
\hline No. & $\begin{array}{c}\text { Kode } \\
\text { Anggota }\end{array}$ & $\begin{array}{c}\text { Cabang } \\
\text { Lari }\end{array}$ & $\begin{array}{l}\text { Cabang } \\
\text { Lompat }\end{array}$ & $\begin{array}{l}\text { Cabang } \\
\text { Lempar }\end{array}$ & Keputusan \\
\hline 1. & A001 & 3,04 & 1,72 & 2,2 & Lari \\
\hline 2. & A002 & 2,4 & 2,64 & 2,64 & Lompat/Lempar \\
\hline 3. & A003 & 2,88 & 2,52 & 2,64 & Lari \\
\hline 4. & A004 & 3,04 & 1,96 & 2,44 & Lari \\
\hline 5. & A005 & 3,36 & 2,28 & 2,64 & Lari \\
\hline 6. & A006 & 3,36 & 2,28 & 2,64 & Lari \\
\hline 7. & A007 & 2,84 & 2,6 & 2,48 & Lari \\
\hline 8. & A008 & 2,92 & 2,68 & 2,8 & Lari \\
\hline 9. & A009 & 2,44 & 2,8 & 2,56 & Lompat \\
\hline 10. & A010 & 2,44 & 2,8 & 2,32 & Lompat \\
\hline 11. & A011 & 1,82 & 2,24 & 2,24 & Lompat/Lempar \\
\hline 12. & A012 & 1,88 & 2,24 & 1,76 & Lompat \\
\hline 13. & A013 & 1,88 & 2,24 & 1,76 & Lompat \\
\hline 14. & A014 & 1,92 & 2,52 & 2,52 & Lompat/Lempar \\
\hline 15. & A015 & 2,92 & 2,68 & 2,8 & Lari \\
\hline 16. & A016 & 2,24 & 2,48 & 1,76 & Lompat \\
\hline 17. & A017 & 2,44 & 2,8 & 2,56 & Lompat \\
\hline 18. & A018 & 2,92 & 2,68 & 2,56 & Lari \\
\hline 19. & A019 & 2,4 & 2,76 & 2,28 & Lompat \\
\hline
\end{tabular}

\section{HASIL DAN PEMBAHASAN}

\subsection{Tampilan Halaman Sistem}

Sistem Pendukung Keputusan Penentuan Ekstrakurikuler Atletik ini terdiri dari beberapa halaman diantaranya sebagai berikut :

\section{Halaman Login}




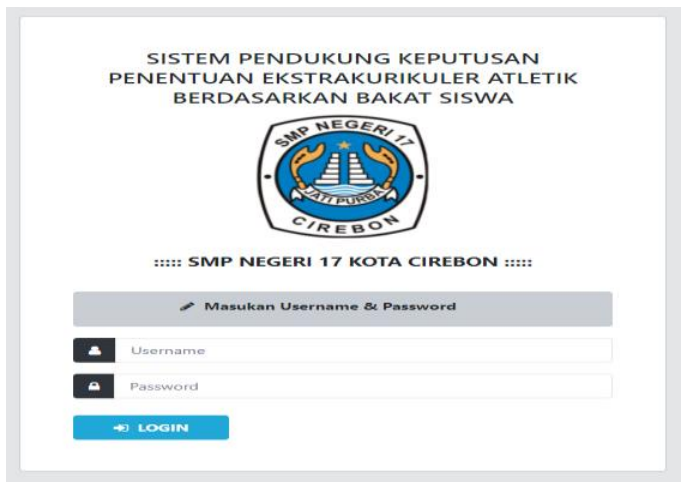

Gambar 1. Halaman Login

Gambar 1 menampilkan halaman login admin \& kepala sekolah. Pada halaman login ini pengguna sistem seperti Admin (Pembina Ekstrakurikuler Atletik) dan Kepala Sekolah dapat masuk ke dalam sistem dengan memasukan username dan password sesuai dengan level user.

\section{Halaman Dashboard Admin}

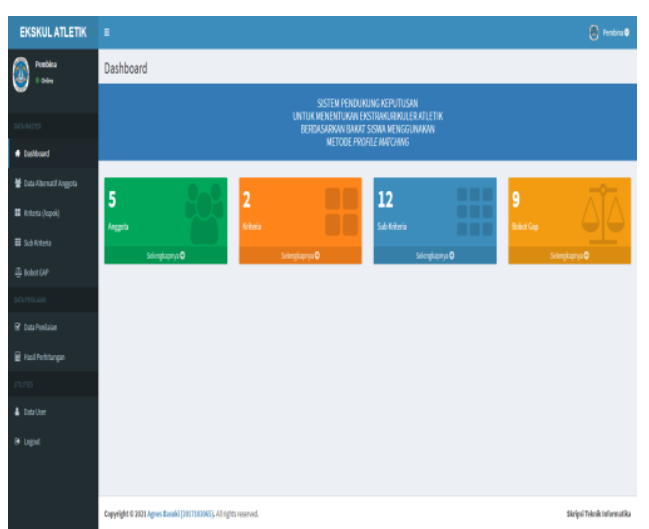

Gambar 2. Halaman Dashboard Admin

Gambar 2 menampilkan halaman dashboard admin. Pembina ekstrakurikuler atletik memiliki hak untuk mengelola seluruh data yang ada pada halaman dashboard admin. Pada halaman dashboard admin terdapat left menu yang terdiri dari data alternatif anggota, kriteria (aspek), sub kriteria, bobot gap, data penilaian, hasil perhitungan, data user, dan logout.

\section{Halaman Data Alternatif Anggota}

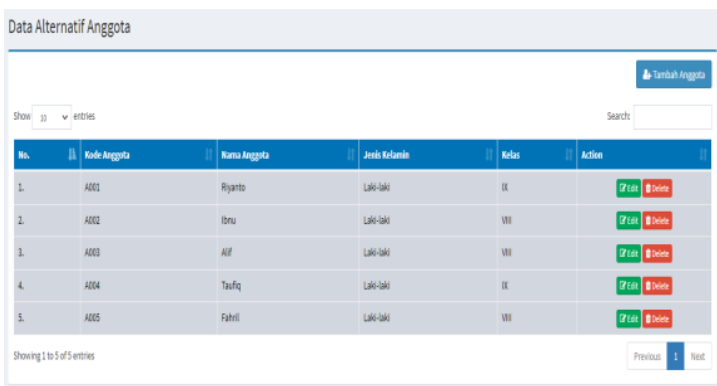

Gambar 3. Halaman Data Alternatif Anggota

Gambar 3 menampilkan halaman data alternatif anggota. Pada halaman ini, Admin dapat melihat dan mengelola data alternatif anggota seperti menambah, mengubah, dan menghapus data.

\section{Halaman Kriteria (Aspek)}

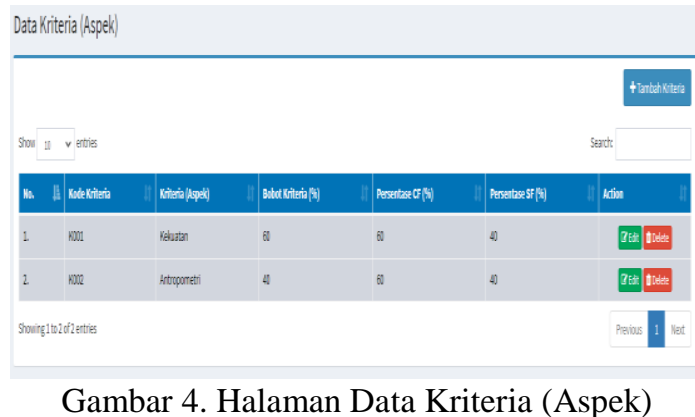

Gambar 4 menampilkan halaman data kriteria (aspek). Pada halaman ini, Admin dapat melihat dan mengelola data kriteria (aspek) seperti menambah, mengubah, dan menghapus data.

\section{Halaman Sub Kriteria}

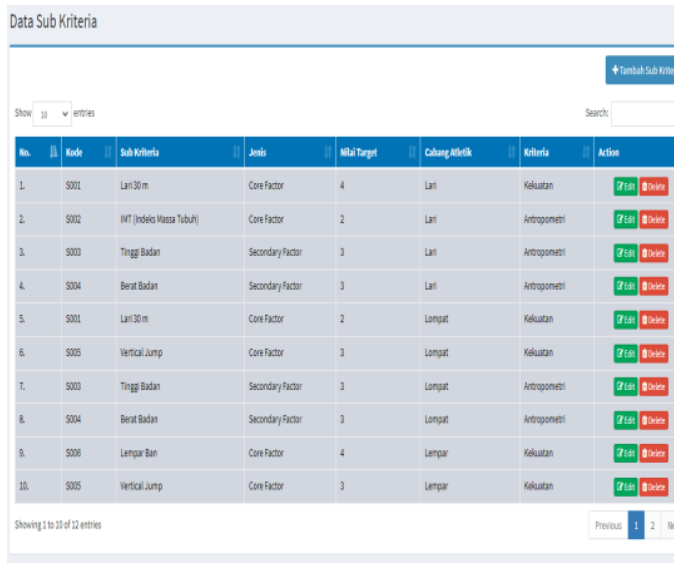

Gambar 5. Halaman Data Sub Kriteria

Gambar 5 menampilkan halaman data sub kriteria. Pada halaman ini, Admin dapat melihat dan mengelola data sub kriteria seperti 
menambah, mengubah, dan menghapus data.

\section{Halaman Bobot Gap}

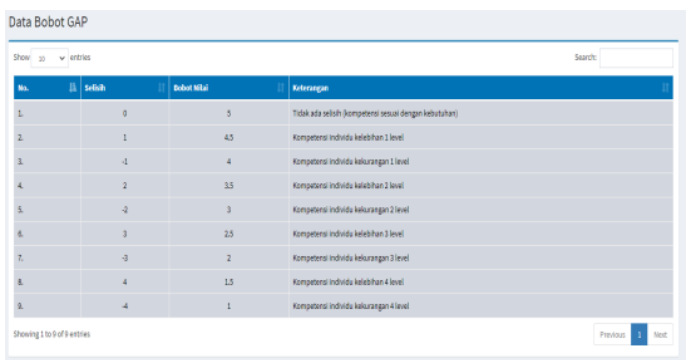

Gambar 6. Halaman Data Bobot Gap

Gambar 6 menampilkan halaman data bobot Gap. Pada halaman ini, Admin hanya dapat melihat data bobot Gap.

\section{Halaman Data Penilaian}

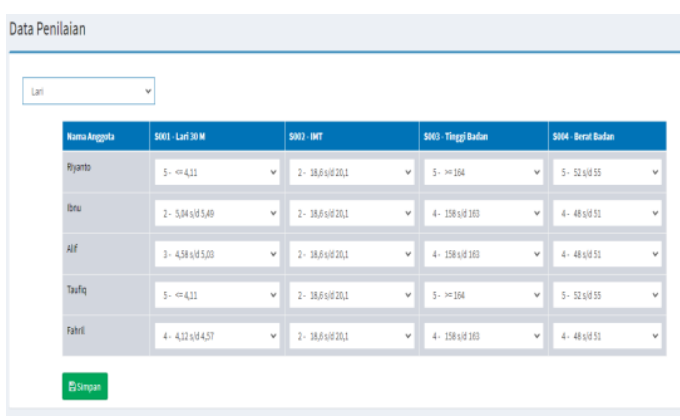

Gambar 7. Halaman Data Penilaian - Lari

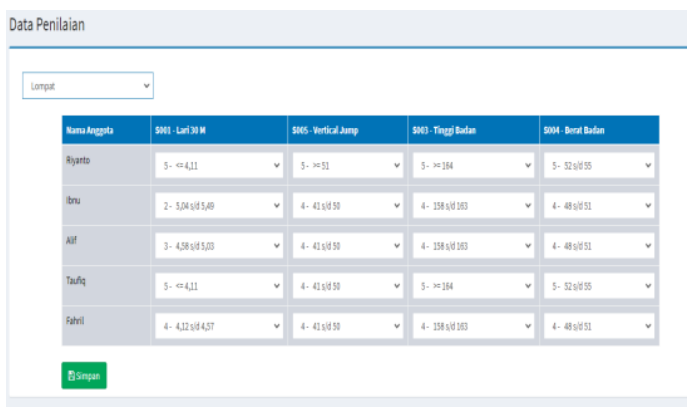

Gambar 8. Halaman Penilaian - Lompat

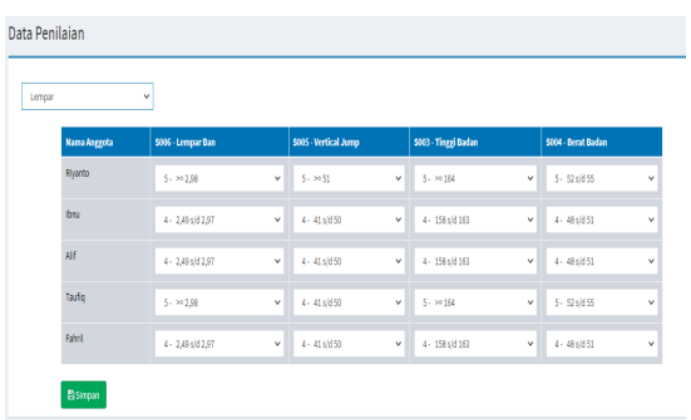

Gambar 9. Halaman Penilaian - Lempar

Gambar 7, 8, 9. menampilkan halaman data penilaian. Pada halaman ini, Admin dapat melihat dan mengelola data penilaian seperti menambah, dan mengubah data.

\section{Halaman Hasil Perhitungan Metode Profile Matching}

Halaman hasil perhitungan metode profile matching ini dapat diakses oleh Admin dan Kepala Sekolah.

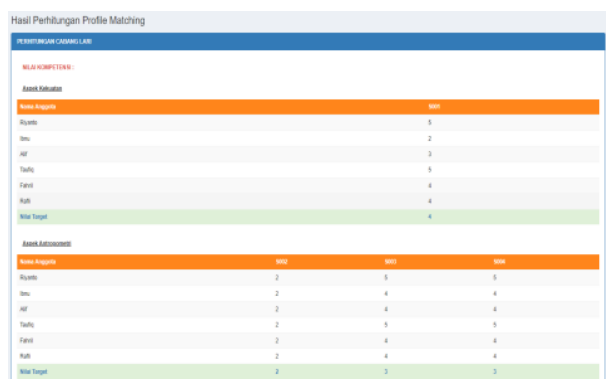

Gambar 10. Halaman Hasil Perhitungan Metode Profile Matching - Nilai Kompetensi

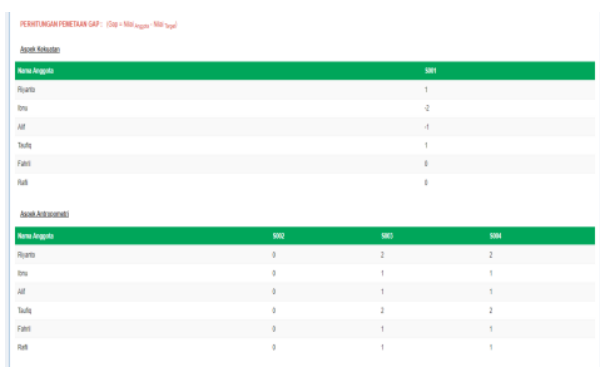

Gambar 11. Halaman Hasil Perhitungan Metode Profile Matching - Pemetaan Gap

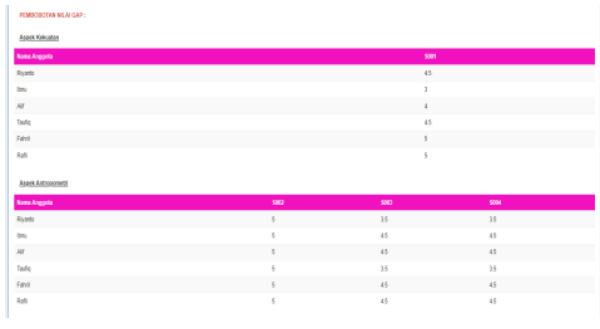

Gambar 12. Halaman Hasil Perhitungan Metode Profile Matching - Pembobotan Nilai Gap 


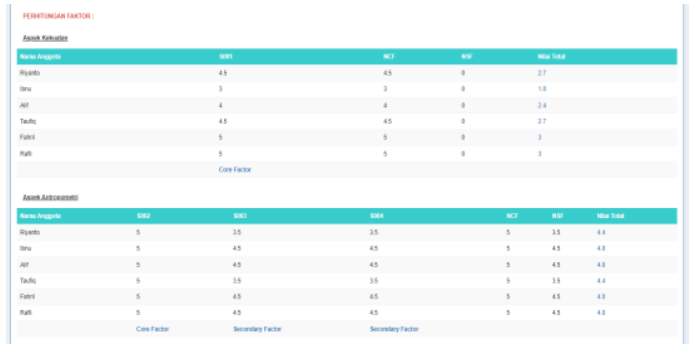

Gambar 13. Halaman Hasil Perhitungan Metode Profile Matching - Perhitungan Faktor

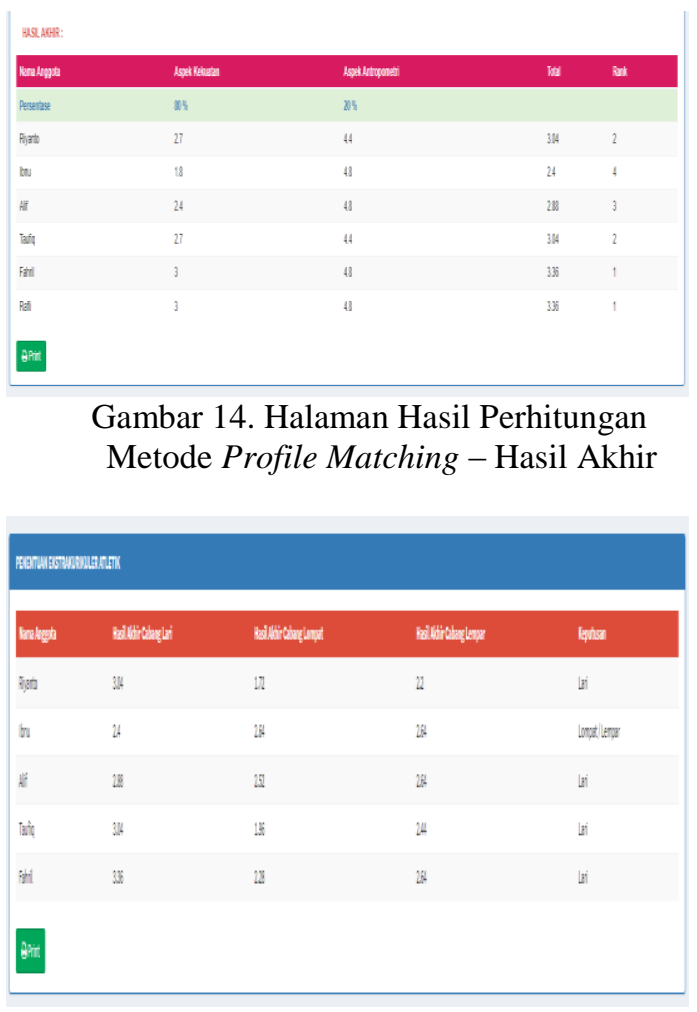

Gambar 15. Halaman Hasil Perhitungan Metode Profile Matching - Penentuan

9. Laporan Penentuan Ekstrakurikuler Atletik Admin dan Kepala Sekolah dapat mencetak laporan hasil perangkingan dari masing-masing cabang atletik dan juga laporan penentuan ekstrakurikuler atletik dengan mengklik button Print pada halaman hasil perhitungan.

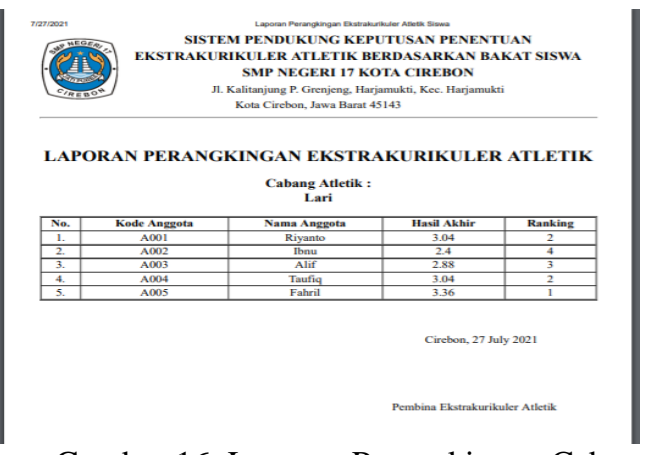

Gambar 16. Laporan Perangkingan Cabang Atletik Lari

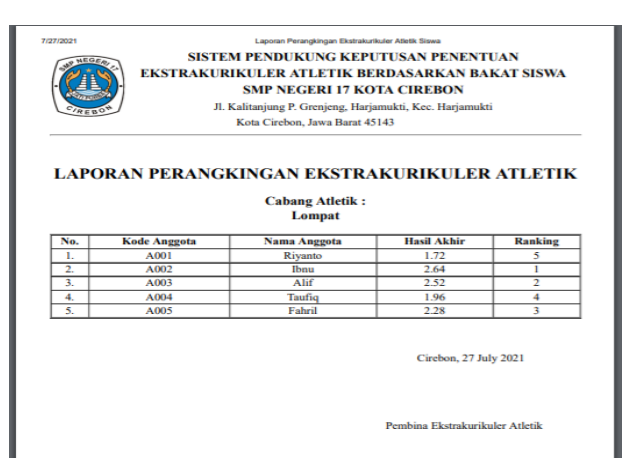

Gambar 17. Laporan Perangkingan Cabang Atletik Lompat

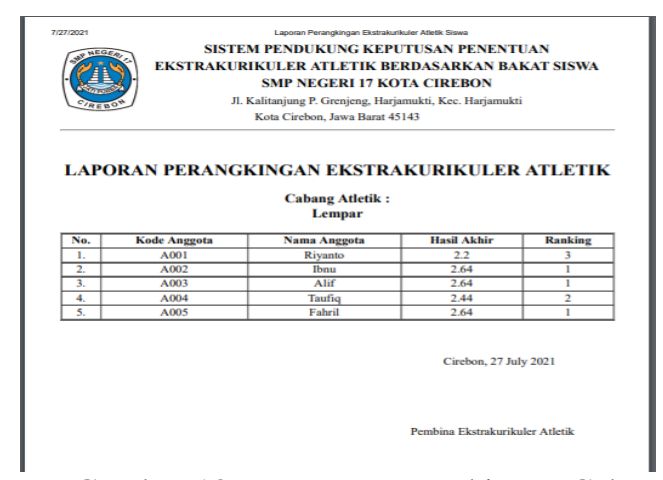

Gambar 18. Laporan Perangkingan Cabang Atletik Lempar

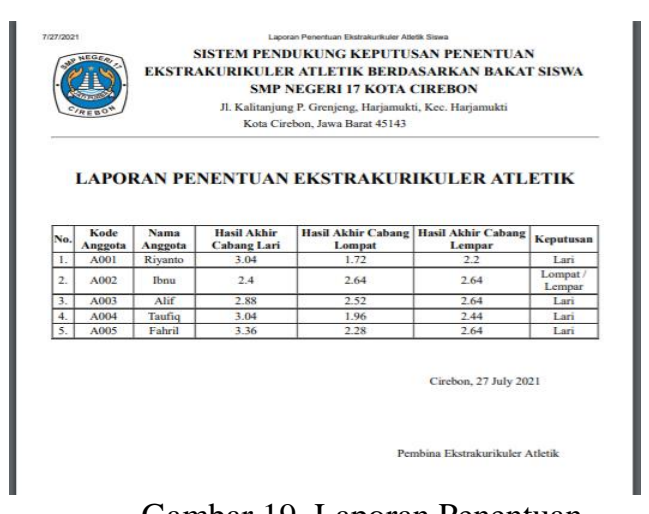

Gambar 19. Laporan Penentuan Ekstrakurikuler Atletik 


\subsection{Pengujian Keberhasilan Perhitungan}

Pengujian keberhasilan perhitungan dilakukan untuk mengetahui sejauh mana tingkat keberhasilan perhitungan yang telah dibangun. Data yang digunakan untuk untuk menguji tingkat keberhasilan perhitungan yaitu hasil perhitungan manual dibandingkan dengan hasil sistem.

Tabel 27. Pengujian Keberhasilan Perhitungan

\begin{tabular}{|c|c|c|c|c|}
\hline $\begin{array}{l}\mathbf{N} \\
\mathbf{0 .}\end{array}$ & $\begin{array}{c}\text { Kode } \\
\text { Angg } \\
\text { ota }\end{array}$ & $\begin{array}{c}\text { Hasil } \\
\text { Manual }\end{array}$ & $\begin{array}{c}\text { Hasil } \\
\text { Sistem }\end{array}$ & $\begin{array}{c}\text { Ketera } \\
\text { ngan }\end{array}$ \\
\hline 1. & A001 & Lari & Lari & Sesuai \\
\hline 2. & A002 & $\begin{array}{c}\text { Lompat/L } \\
\text { empar }\end{array}$ & $\begin{array}{l}\text { Lempar/ } \\
\text { Lompat }\end{array}$ & Sesuai \\
\hline 3. & A003 & Lari & Lari & Sesuai \\
\hline 4. & A004 & Lari & Lari & Sesuai \\
\hline 5. & $\mathrm{~A} 005$ & Lari & Lari & Sesuai \\
\hline 6. & A006 & Lari & Lari & Sesuai \\
\hline 7. & A007 & Lari & Lari & Sesuai \\
\hline 8. & A008 & Lari & Lari & Sesuai \\
\hline 9. & A009 & Lompat & Lompat & Sesuai \\
\hline $\begin{array}{l}1 \\
0 .\end{array}$ & A010 & Lompat & Lompat & Sesuai \\
\hline $\begin{array}{l}1 \\
1 .\end{array}$ & A011 & $\begin{array}{c}\text { Lompat/L } \\
\text { empar }\end{array}$ & $\begin{array}{l}\text { Lempar/ } \\
\text { Lompat }\end{array}$ & Sesuai \\
\hline $\begin{array}{l}1 \\
2 .\end{array}$ & A012 & Lompat & Lompat & Sesuai \\
\hline $\begin{array}{l}1 \\
3 .\end{array}$ & A013 & Lompat & Lompat & Sesuai \\
\hline $\begin{array}{l}1 \\
4 . \\
\end{array}$ & A014 & $\begin{array}{c}\text { Lompat/L } \\
\text { empar }\end{array}$ & $\begin{array}{l}\text { Lempar/ } \\
\text { Lompat }\end{array}$ & Sesuai \\
\hline $\begin{array}{l}1 \\
5 .\end{array}$ & A015 & Lari & Lari & Sesuai \\
\hline $\begin{array}{l}1 \\
6 . \\
\end{array}$ & A016 & Lompat & Lompat & Sesuai \\
\hline $\begin{array}{l}1 \\
7 .\end{array}$ & A017 & Lompat & Lompat & Sesuai \\
\hline $\begin{array}{l}1 \\
8 .\end{array}$ & A018 & Lari & Lari & Sesuai \\
\hline $\begin{array}{l}9 \\
9 .\end{array}$ & A019 & Lompat & Lompat & Sesuai \\
\hline
\end{tabular}

Tingkat keberhasilan perhitungan didapatkan dari perhitungan menggunakan persamaan 6 .

$$
\frac{\text { jumlah data benar }}{\text { total data uji }} x \mathbf{1 0 0} \%
$$

Berdasarkan perbandingan data pada tabel 27, maka dapat diperoleh hasil tingkat keberhasilan perhitungan sebagai berikut :

$$
\begin{gathered}
\text { Tingkat Keberhasilan }=\frac{19}{19} x 100 \% \\
=100 \%
\end{gathered}
$$

\section{KESIMPULAN DAN SARAN}

\subsection{KESIMPULAN}

Berdasarkan hasil pembuatan Sistem pendukung keputusan penentuan ekstrakurikuler atletik berdasarkan bakat siswa menggunakan metode profile matching pada SMP Negeri 17 Kota Cirebon dapat disimpulkan sebagai berikut :

1. Sistem ini dapat digunakan untuk membantu Pembina ekstrakurikuler atletik dalam menentukan bakat atletik siswa dengan hasil persentase keberhasilan perhitungan $100 \%$.

2. Dengan menerapkan metode profile matching hasil yang didapatkan lebih objektif dan lebih cepat dalam menentukan ekstrakurikuler atletik siswa.

3. Pembina ekstrakurikuler dapat lebih mudah ketika mencari data-data siswa yang memiliki potensi di bidang atletik.

\subsection{SARAN}

Dalam pembuatan Sistem pendukung keputusan penentuan ekstrakurikuler atletik berdasarkan bakat siswa menggunakan metode profile matching pada SMP Negeri 17 Kota Cirebon ini, penulis menyadari masih terdapat kekurangan. Adapun saran-saran yang dapat penulis berikan untuk pengembangan aplikasi selanjutnya antara lain sebagai berikut :

1. Sistem ini dapat dikembangkan dengan menambah metode sistem pendukung keputusan yang lain sehingga dapat memberikan perbandingan untuk hasil keputusan penentuan ekstrakurikuler atletik yang diberikan.

2. Pengembangan sistem selanjutnya dapat ditambahkan kriteria (aspek) penilaian lain yang digunakan untuk menentukan ekstrakurikuler atletik 
siswa.

\section{DAFTAR PUSTAKA}

[1] S. Aisyah, "APLIKASI SISTEM PENDUKUNG KEPUTUSAN ANALISIS KELAYAKAN PEMBERIAN KREDIT MENGGUNAKAN METODE SAW PADA PERUSAHAAN LEASING," Jurnal Teknovasi, vol. 06, no. 01, pp. 1-16, 2019.

[2] I. N. Farida and R. Firliana, "Implementasi Metode Profile Matching Untuk Evaluasi Potensi Akademik Penjurusan Siswa MAN 2 Kota Kediri," Jurnal Infotel, vol. 8, no. 2, pp. 156-163, November 2016.

[3] Y. E. Nopiyanto and S. Raibowo, DASARDASAR ATLETIK, Bengkulu: Elmarkazi, 2020.

[4] Y. E. Nopiyanto, S. Raibowo and Drs. Arwin, PEMBELAJARAN ATLETIK, Bengkulu: Elmarkazi, 2020.

[5] Azwar and F. N. Masi, "PENENTUAN MINAT

SISWA MENGGUNAKAN METODE PROFILE MATCHING," Celebes Computer Science Journal, vol. 2, no. 2, pp. 16-26, Oktober 2020 . 